\title{
Late Glacial and Holocene avulsions of the Rio Pastaza Megafan (Ecuador-Peru): Frequency and controlling factors
}

\author{
Carolina Bernal, Frédéric Christophoul, José Darrozes, \\ jean-Claude Soula, Patrice Baby, José Burgos. \\ International Journal of Earth Sciences (2011), 100, 1759-1782 \\ DOI 10.1007/s00531-010-0555-9 \\ hal-00536576
}

C. Bernal, F. Christophoul, J-C. Soula, J. Darrozes and P. Baby, UMR 5563 GET, Université de Toulouse-CNRS-IRD-OMPCNES,14 Avenue Edouard Belin, 31400 Toulouse, France. frederic.christophoul@get.obs-mip.fr

\author{
C. Bernal, chavelacarola@yahoo.com.mx \\ J-C. Soula, soula@get.obs-mip.fr \\ J. Darrozes, darrozes@get.obs-mip.fr \\ Patrice Baby, patrice.baby@ird.fr \\ J. Burgos, \\ Petroamazonas, Av. Naciones Unidas E7-95 y Shyris, Quito, \\ Ecuador, 4to piso, Quito, Ecuador \\ jose_burgos@petroamazonas.ec
}

ABSTRACT The geomorphological study by mean of remote sensing imagery of the Rio Pastaza Megafan (Ecuador and northern Peru), reveals the traces of numerous avulsions. 108 avulsion sites have been defined. The location of these sites, the available radiocarbon ages as well as historical maps of the $17^{\text {th }}$ century, enable us to propose an evolution history of the migration and avulsions of the Rio Pastaza since the Last Glacial Maximum. The first avulsions of the Río Pastaza occurred after the LGM in a zone close to and roughly parallel to the sudandean front, where the developed avulsion gave a distributive pattern to the ancient stream of the Río Pastaza in an area located between the modern Río Morona and Pastaza, where they caused the Rio Pastaza to develop a fan-like distributary pattern. This is interpreted as a response to thrust related forelimb tilt, progressively shifting eastward the Rio Pastaza and the apex of the megafan. This sequence of events ended with the Great Diversion of the Rio Pastaza toward the modern Rios Corrientes and Tigre. Avulsions occurred in the TigreCorrientes Area between 9200 and 8500 yrsCal BP. Afterward, the Río Pastaza was diverted to its present-day north-south course. This last significant avulsion occurred before AD 1691. In the area located between the modern Río Morona and Pastaza, avulsion frequency - probably overestimated - ranges between 100 to $200 \mathrm{yrs}$. In the Ríos Tigre and Corrientes area, avulsion frequency - probably underestimated - ranges from 300 to 400 yrs. Regional tectonics is likely to have triggered most of the avulsions in the Morona-Pastaza area but its influence is restricted to this area. The factors controlling the avulsions in the TigreCorrientes area are less clear because the frequently described "hydrologic"-driven avulsion as observed in areas characterized by contrasted hydrologic cycles are inconsistent with the characteristics of the hydrologic cycles of the Rio Pastaza.

Keywords : Avulsion, megafan, Amazonia, controlling

factors, post-LGM, tectonics

\section{Introduction}

Fluvial megafans form as rivers exit the topographic front of a mountain and play a major role in the dispersal of sediments and sedimentation in overfilled foreland basins (Leier et al. 2005).

Because of their size and mean slope, megafans constitute specific geomorphic units. Whereas smallersized alluvial fans involve deposition of successive lobes as the main process of sediment accumulation (Blair and McPherson 1992; Schumm et al. 1987), sedimentation in megafans is dominated by avulsion and bifurcation of the main streams (Bridge and Karssenberg, 2005). Style of avulsions (Slingerland and Smith, 2004) in megafans as well as their frequency strongly influences the sedimentation rate and the stratigraphic architecture. Numerous studies have been carried out on the typology and frequency of avulsion and characteristics of anastomosis in deltas (Törnqvist, 1994; Stouthamer and Berendsen, 2000; Stouthamer and Berendsen, 2001), and alluvial plains (Nelson, 1970; Saucier, 1994; Autin et al., 1991; Morozova and Smith, 1999; Morozova and Smith, 2000). Megafans have been less considered (Gole and Chitale, 1966; Gohain and Parkash, 1990; Singh et al., 1993; Assine, 2005; Assine and Soares, 2004). However, because of their size, slope and situation in the piedmont of mountain fronts, the question arises of the specificity of megafans in terms of causes and triggers of avulsion, and, in particular, the balance between tectonics and sedimentary/climatic events.

This study focuses on the Napo-Pastaza megafan in the northern Andes. This megafan is located on the Amazonian foothills of Ecuador and northern Peru, roughly between $2^{\circ} 00$ and $5^{\circ} 00 \mathrm{~S}$ and between $74^{\circ} 00 \mathrm{~W}$ and $78^{\circ} 00 \mathrm{~W}$. It covers $51400 \mathrm{~km}^{2}$ (Fig. 1). This study is based on the mapping of the successive courses of the Rio Pastaza and its main tributaries, mainly from remote sensing and DEM analyses. The aim of this paper is to establish the relative chronology, the average frequency and the style of the avulsions in the past $20000 \mathrm{yrs}$ and to discuss the causes and triggers of these avulsions as functions of the different entities which have formed the megafan system. Dynamics of avulsion in the Pastaza megafan will be then compared with other areas known for frequent avulsions.

\section{2 - General setting}

\section{1 - Geology and geomorphology}

\subsection{1. - Structural organization}

The part of the Ecuadorian Andes involved in the Amazonian drainage can be divided into 4 morphotectonic 
units which are, from west to east: the Western Cordillera, Puyo plateau. The plateau surface appears as a low angle the Interandean depression, the Eastern Cordillera, the weathered and hardened surface cut through the uppermost Subandean zone and the Amazonian foreland (Fig. 1). Pleistocene Mera megafan (Mera surface, Heine, 1994,

The Western Cordillera and Interandean Depression are Heine, 2000; Bes de Berc et al. 2005). The same surface is constituted by Upper Cretaceous-Paleogene formations, found in the upper Amazonian foreland (Villano surface, mainly andesitic (Reynaud et al., 1999; Lavenu et al. 1992; Fig. 1 and 2) here it forms another but highly dissected Kennerley 1980) unconformably overlain by neogene plateau. Arching and backtilting of the Puyo plateau as andesitic formations affected by late Miocene to early consequences of the propagation of the Subandean Frontal Pleistocene deformations (Lavenu et al., 1992; Barragan et Thrust (Bes de Berc et al. 2005) caused beheading or al., 1996; Hungerbühler et al., 2002; Winkler et al., 2005) diversions of the transverse rivers - including the Pastaza and Quaternary volcanic formations (Kennerley 1980; River - which formerly flowed eastward into the Barberi et al. 1988; Lavenu et al. 1992).

Amazonian plain (Bès de Berc et al. 2005; Burgos,

The Eastern Cordillera consists in Paleozoic 2006). The tectonic offset between the Puyo and Villano through upper Cretaceous rocks, metamorphosed and plateaus reaches $\sim 450 \mathrm{~m}$ in the centre of the arch and deformed during late Cretaceous to Paleocene time (Pratt decreases progressively sideways. The Mera erosional et al. 2005), eroded and then blanketed by late Miocene to surface formed between $\sim 23-24{ }^{14} \mathrm{C}$ ky BP which is the age Pliocene volcanic/volcanoclastic formations and of the younger sediment cut by the surface, and $\sim 18{ }^{14} \mathrm{C} \mathrm{ky}$ Quaternary volcanics (Lavenu et al. 1992). Apatite fission BP which is the age of the older deposits along rivers track analyses and $\mathrm{U}-\mathrm{Th} / \mathrm{He}$ measurements indicate a incising the surface (Bès de Berc et al., 2005). As this moderate to slow uplift from the Miocene to the late period corresponds to the time of deposition of the Last Pliocene (Spikings et al., 2000; Spikings and Crowhurst, Glacial Maximum (LGM) terminal moraines (Heine, 2000) 2004). the formation of the surface can be ascribed to the LGM.

The Subandean zone is separated from the Eastern Therefore, arching and backtilting of this surface and the Cordillera by the west dipping Subandean Thrust fault. The consecutive diversion of the Rio Pastaza were younger Subandean Zone comprises in the west the Abitagua than the LGM.

Cordillera, and in the east two thrust-related antiformal thrust stacks (as defined by e.g. McClay, 1992), locally known as the Napo and Cutucu "uplifts", involving Jurassic through Neogene formations. These antiformal

2.1.3. - The Rio Pastaza catchment upstream of the Amazonian domain

The Rio Pastaza forms by the confluence of two stacks appear as axial culminations (in the sense of longitudinal rivers flowing in the Interandean Depression Ramsay, 1967 p. 346, Ramsay \& Huber, 1987) separated (Fig.1 and 2). Downstream of this confluence, the Rio by an axial depression known as the Pastaza depression. Pastaza crosses the Eastern Cordillera along a deep ( $>$ The Pastaza depression is filled with middle (?) through $2200 \mathrm{~m}$ ) and narrow transverse valley (Fig. 1). In the Upper Pleistocene piedmont deposits (Mera formation) Subandean Fault Zone and the western Puyo plateau, the which formed the apex of the Mera megafan (Tschopp Pastaza valley becomes much wider and shallow showing 1953; Baby et al. 1999; Bes de Berc et al. 2005). stepped degradational terraces (Bes de Berc et al. 2005). In

In front of the Subandean Zone the Amazonian basin the central Puyo plateau, the Rio Pastaza traverses a preserves a sedimentary stack ranging from Paleozoic to preserved Pliocene volcanic complex. The overall flow Oligocene overlying the Brazilian shield. Fluvial direction is there toward the south-southeast. The area of aggradation occurred there since $\sim 22 \mathrm{Ma}$ accumulating the Pastaza catchment upstream of its debouchement in the sediments issued from the west (Christophoul et al. 2002; Amazonian plain is $13700 \mathrm{~km}^{2}$. Measurements of vertical Burgos 2006) to build a very large megafan. This large incision rates in the Eastern Cordillera since the LGM have megafan termed hereafter Neogene megafan corresponds given values ranging from 0.5 to $0.67 \mathrm{~cm}^{-1} \mathrm{car}^{-1}$, increasing to the present day basins of the left bank tributaries of the from the LGM to now, resulting from a rapid uplift, up to 1 Rio Maranon (including the Rio Pastaza) and those of the $\mathrm{cm}_{\text {year }}{ }^{-1}$ in front of the Abitagua cordillera (Bès de Berc et right bank tributaries of the Rio Napo. It can be shown that al., 2005). The deep incision of the Eastern Cordillera by the apex of this fan migrated eastward from the early the Pastaza valley indicates that a rather rapid uplift of at Miocene to now as a result of the forward propagation of least $2 \mathrm{~mm}$ year ${ }^{-1}$ succeeded the Miocene through middle the mountain front (Christophoul et al., 2002; Bes de Berc Pliocene period of slow denudation and uplift evidenced et al., 2005; Burgos, 2006). In the east of the megafan, an by the Apatite fission tracks analyses and U-Th/He elongated flat-topped topographic high striking $\mathrm{N} 130^{\circ}$, measurements of Spiking et al. (2000) and Spiking and interpreted to be the exhumed Upper Miocene forebulge Crowhurst (2004). Denudation rate, greater than $\sim 0.2 \mathrm{~mm}$ (Iquitos Arch in Roddaz et al. 2005), appears as an area of year ${ }^{-1}$ in average and locally as high as $0.4 \mathrm{~mm}^{-1}$ year have no- or limited Neogene deposition. The active part of the been obtained in the Eastern Cordillera by Vanacker et al. megafan (the modern Pastaza megafan) is located in the (2007) from cosmogenic radionuclide $\left({ }^{10} \mathrm{Be}\right)$ studies.

south-western side of the Neogene megafan, including the left-bank tributaries of the Rio Morona-Santiago, the lower Rio Pastaza, and the right-bank tributaries of the Rios Tigre and Corrientes.

\subsection{2 - The Puyo Plateau}

\section{2 - Climatic setting}

\subsection{1 - Late Pleistocene and Holocene climate}

Several authors (Hastenrath, 1981; Hastenrath and Kutzbach, 1985; Heine and Heine, 1996; Heine, 2000)

The 'Pastaza depression' appears as a very gentle consider the LGM to have been a cooler and more arid arch dipping $0.4-0.5^{\circ}$ west in its central part known as the period responsible for the lack of sediment in the Brazilian 
lowland between 24 and $17 \mathrm{ky}$ (Ledru et al.; 1998) whereas Seltzer et al. (2002) indicate cool but wet conditions from 30 to $15 \mathrm{ky}$ in the Peruvian Altiplano. In Ecuador, the LGM moraines are ${ }^{14} \mathrm{C}$ dated between 25 and $15 \mathrm{ky}$ although the maximum extent of glaciers is inferred to nor have occurred between 30 and $25{ }^{14} \mathrm{C}$ ky BP (Heine, 2000). Am According to the latter author, the retreat of glaciers in eastern Ecuador continuously submitted to the humid between 25 and $16{ }^{14} \mathrm{C}$ ky BP was due to glacier shrink Atlantic winds no unusual floods were signalled during the because of increased aridity (increased insolation and 1982-1983 and 1997-1998 events. Similarly, no decreased precipitations) and not to warming (Heine, catastrophic floods have been registered for the $17^{\text {th }}$ 2000). Increased aridity can explain the development of an century events in the catalogue of major historical disasters erosion surface involving soil creeping and sheetflooding in eastern Ecuador with the reserve that chronicles of that rather than fluvial incision and transport (e.g. Leeder et al., time seem to have been little concerned with eastern 1998). In the southern interandean depression, pollen Ecuador.

analyses indicate that climate was cooler and moister than today during the late-glacial period $(17-11$ cal. ky BP, Rodbell et al., 1999; Hansen et al., 2003). However, the vegetational changes in the Interandean Depression may have been influenced by winds from the west as well as from the east (Hansen et al., 2003) and these results are not necessarily applicable to the Amazonian basin much more influenced by the humid Atlantic winds.

For Clapperton et al. (1997) a significant re-advance of 1980; Barberi et al., 1988; Barragan et al., 1996; glaciers occurred during the Younger Dryas (11 to $10{ }^{14} \mathrm{C}$ Hungerbühler et al., 1995; Winkler et al., 2005).

ky BP) whereas for Heine and Heine (1996) and Heine (2000) this advance of glaciers took place at least 500 years later.

The climatic data for the Holocene have been inferred from vegetational changesin the Interandean Depression (Rodbell et al., 1999; Hansen et al., 2003) and in the ind northern side of the Neogene megafan (Yasuni National Park, northeast of Ecuador, Weng et al., 2002). Weng et in al.'s (2002) palynological studies indicate that tropical rain forest has developed throughout the Holocene with minor climatic oscillations. According to these authors, severe Pleistocene (Spikings et al, 2000; Spikings and Crowhurst, droughts occurred in the period 8700-5800 cal years BP, 2004). Since the Rio Pastaza has incised the eastern which should be correlated with other records from Cordillera more than 2000m (Fig.1), these results support Amazonia, adjacent savannas and the Andes (Hastenrath the interpretation that deformation and related uplift of the and Kutzbach, 1985; Frost, 1988; Behling and Eastern Cordillera was Pleistocene in age.

Hooghiemstra, 1998, 1999). This "dry" period was In the frontal Eastern Cordillera and the Subandean succeeded by more uniform and wetter conditions with Zone, a tectono-sedimentary and geomorphic study alternating wetter and drier millennial-scale events (Weng supported by ${ }^{14} \mathrm{C}$ dating indicate a tectonic activity related et al., 2002).

\subsection{2 - The ENSO events}

ENSO (El Nino Southern Oscillation) events have been recorded in Ecuador and neighbouring areas since the late Pleistocene. According to Keefer et al. (2003) studying deposits in the Pacific side of the Northern Peruvian Andes, 10 severe ENSO events occurred between 38,200 and $12,900 \mathrm{cal}$ years. In the southern Interandean of the Depression of Ecuador, Rodbell et al. (1999) and Moy et historical events with intensity $\geq$ VIII have been recorded al. (2002) studying storm-induced lake deposits found that between AD1541 and AD 1995 (IGEPN, 1999). One event ENSO events became significant only after $\sim 5 \mathrm{ky} \mathrm{BP}$, with of intensity XI has occurred in AD1797 (MsNOAA highest spectral density and frequencies between $\sim 3.5$ and magnitude 8.30, NOAA Catalog, U.S. Geological Survey, $2.6 \mathrm{ky}$ and during the last 660 years. The reduced ENSO 2003), and two events of intensity $\mathrm{X}$ in AD1698 activity should be correlated with the severe droughts of (MsNOAA magnitude 7.70) and AD1949 (MsNOAA the period 8700-5800 cal years BP inferred by Weng et al. magnitude 6.80). Most of these events are situated in the (2002) whereas the increased ENSO activity should be Eastern Cordillera and the Subandean Zone. The rare correlated with the following wetter period. The $17^{\text {th }}$ and events situated under the Pastaza megafan were deep $20^{\text {th }}$ centuries are also characterized by very strong ENSO events which are likely to have had no influence on the events (Cobb et al. 2003; Keefer et al., 2003) and the last drainage network.

very severe events occurred in the years 1982-1983 and 


\section{4 - Landslides}

transported by Pastaza's tributaries (IGEPN, 2009). An ash

Earthquakes-triggered landslides were observed in the layer of $\sim 6 \times 10^{6} \mathrm{~m}^{3}$ was deposited in August 2001 near Eastern Cordillera such as those triggered by the 5 March Baños and the Patate/Chambo confluence (Le Pennec et 1987 M 7 event (Hall, 1991). In eastern Ecuador, the al., 2008).

major landslides not triggered by earthquakes were Sangay volcano is the most active volcano in the independent of the ENSO events (for example, the La Northern Vocanic Zone of the Andes and a permanent Josefina landslide, the greatest known in Ecuador, occurred explosive activity has been observed since 1628 with an in 1993, Demoraes and D'Ercole, 2001). Moreover, no average recurrence time of large eruptions of less than 50 landslides related to the severe and frequent $17^{\text {th }}$ century years. The early Sangay III lava flows are older than LGM ENSO events are registered in the catalogue of major moraines (Monzier et al. 1999). The activity is of a historical disasters and no landslide formed during the Strombolian type with block and ash explosions, ash falls, 1982-1983 and 1997-1998 events (Demoraes and pyroclastic flows and lahars (see Monzier et al., 1999).

D'Ercole, 2001). Whatever their trigger, the sediments The direct impact of these eruptions on the Amazonian delivered by these major landslides were incised and Pastaza system is difficult to appreciate. For example, the entirely removed by rivers a few days after the disaster 4500 years-old lahars generated at the Cotopaxi cap, (e.g. Hall, 1991) with no avulsion observed downstream. although gigantic, are not observed downstream of the In any event, no major landslides have been registered in Patate - Chambo confluence. The lahars produced by the the valleys of the Rio Pastaza and major tributaries, and a 3000 years BP sector collapse of the Tungurahua have careful observation of satellite images and air photos has been observed in none of the terraces of the Rio Pastaza shown no well characterized landslide scars in the upper downstream of the immediate proximity of the volcano Pastaza basin.

\section{5 - Volcanic eruptions}

(Bès de Berc et al., 2005). The large historical pyroclastic flows of the Tungurahua have been largely contained within the channel cut by a tributary to the Pastaza and did

Ecuador is characterized by 20 active volcanoes (e.g. not reach this river (Stinton and Sheridan, 2008). However, Hall, 1977; Hall and Beate, 1991; Hall et al., 2008). Four in the upper Pastaza valley, near Baños, the T2 terrace of the most important active or recently active volcanoes, covered with a lava flow dated between $\sim 2200$ and $\sim 1500$ Chimborazo, Cotopaxi, Tungurahua, and Sangay are ${ }^{14} \mathrm{C}$ years BP (Hall et al., 1999) overlies fluvial deposits within, or at the boundary of, the Pastaza drainage basin made of reworked volcanic material (Bès de Berc et al., (Fig.1). 2005). Volcanic material reworked by fluvial transport has

Chimborazo volcano was active in the late Pleistocene also been observed in a low terrace cut into the Middle (Hall and Beate 1991; Barba et al., 2008) and the Holocene Pleistocene volcanic hills of the Puyo plateau (Burgos et (between about 8000 and 1000 years ago, Barba et al., al., unpublished). Deposits from the eastern flank of 2008). The first two of the major Holocene events Sangay III have been stocked in the Sangay fan (Monzier generated large pyroclastic deposits and thick lahars. et al., 1999) and it is unlikely that more than a minor part Pyroclastic deposits are described for 5 other major of these deposits was introduced en masse into the Pastaza eruptions occurring until the $5^{\text {th }}$ to $7^{\text {th }}$ centuries (Barba et network after each eruption.

al., 2008).

The volume of material input by the volcanic eruptions

Cotopaxi volcano had numerous eruptions producing in the Pastaza network is more difficult to estimate because andesitic scoria and pumice ash flows, blocky lava flows, only the volume of exceptional or recent events has been and lahars $(\sim 30$ eruptions since 1530, Hall, 1977). At least calculated. The volumes of material for these exceptional four rhyolitic eruptions occurred during the past 10000 events are $\sim<2 \mathrm{~km}^{3}$ for the Chimborazo; $2.5 \mathrm{~km}^{3}$ for the years. A very large $\left(\sim 71000 \mathrm{~m}^{3}\right)$ debris flow (lahar) Cotopaxi giant lahar to which could be added a volume of occurring $\sim 4500$ years ago flowed $>130 \mathrm{~km}$ east and south $\sim 4 \mathrm{~km}^{3}$ representing the 4 rhyolitic eruptions signalled by into the Rio Patate valley. The initial dry volume has been Mothes et al. (1998); the $\sim 3000$ years BP sector collapse of estimated to $\sim 2 \mathrm{~km}^{3}$. The most distinctive lahar deposits of the Tungurahua II mobilized $8 \mathrm{~km}^{3}$ to which could be the historical period occurred in 1877 and in the $18^{\text {th }}$ added associated lahars. The numerous eruptions of lesser century. Since 1906 only small eruptions are signalled with importance mobilized much smaller volumes of material. limited ash falls or pyroclastic flows (IGEPN, 2009) If we assume that each of these eruptions provided although renewed seismic activity has occurred since 2001 approximately the same quantity of material as the 2006 (Molina et al., 2008). Modelling of lahar flows indicate eruption $\left(\sim 510^{-3} \mathrm{~km}^{3}\right)$, and that the frequency of eruptions high discharge rates $\left(\sim 15,000 \mathrm{~m}^{3} \mathrm{~s}^{-1}\right.$, Castro et al., 2006). has remained similar to that of the historical ones, then the

Tungurahua volcano has been active since at least the 30 eruptions have given no more than $\sim 0.15 \mathrm{~km}^{3}$. This late Pleistocene. Tungurahua II, mainly composed of gives a total volume of less than $20 \mathrm{~km}^{3}$ to which must be andesite lava flows younger than $14 \mathrm{ky}$ BP, was partly added the volume of the Sangay deposits which have not destroyed by a collapse event, $2955 \pm 90$ years ago, which been stocked in the Sangay fan.

produced a $8-\mathrm{km} 3$ avalanche on a distance of $\sim 20 \mathrm{~km}$ and

a large lahar (Hall et al., 1999). The eruptive activity of the 3 - Material and Methods

present volcano (Tungarahua III) commenced in the period The avulsions in the Pastaza megafan have been $\sim 2300$ - 1400 years BP (Hall et al., 1999). Lava extrusions studied by means of remote sensing image analysis and pyroclastic flows occurred since the $14^{\text {th }}$ century, because of its size and of the inaccessibility of the greatest notably in 1773, 1886, 1916-18 and 2006-08 (Le Pennec et part of the area. Moreover, the high density of the al., 2008; IGEPN, 2009). During the 1916 and 1918 vegetation and the low topographic amplitude of alluvial eruptions, large amounts of ashes and lapillis were ridges make field identification of abandoned fluvial 
morphologies difficult.

permit to evidence hidden fluvial channels for the optical

This study was performed using Landsat and ASTER (s.1.) Landsat and Aster images. Another interesting images and SRTM DEM. The set of Landsat images used property of the radar wave penetration is its capacity to in this study is summarized in Table 1.

cross the clouds.

The MrSID ${ }^{\mathrm{TM}}$ Landsat 7 images, correspond to a To supplement this study we also used the Shuttle mozaic of 58 images acquired on a period ranging from Radar Topography Mission DEM (SRTM V3 with three 1999 to 2001 (see Table 1). These mozaics extend north- arc second of spatial resolution). Its vertical accuracy is south over 10 degrees of latitude, and span east-west for around $10-15 \mathrm{~m}$ depending on topographic gradient, the full width of the UTM zone. vegetation cover, tropospheric humidity (Welch and Marko These images are processed to change the Landsat 1981; Lang and Welch, 1994). spatial resolution $(30 \mathrm{~m})$ of the multispectral composition. Geomorphologic studies using SRTM data have First, TM7 Band (midle-infrared), is displayed as red, TM4 demonstrated its efficiency (Potts et al., 2008; Zandbergen, band, near-infrared band, is displayed as blue and TM2 2008; Guth, 2006 and among others). For Amazonian band, green band, is displayed as green.

morphology, Rosseti and Valeriano (2007) starting from

The initial pixel size of these bands $(\sim 30 \mathrm{~m})$ is then the example of the Amazon estuary in Brazil demonstrate reduced using cubic interpolation to the spatial resolution the pertinence of using SRTM DEMs for mapping of the panchromatic band (TM8, 15 m).

The process follows with calculation of the Hue- relief, highly vegetated, low areas such as rain forests. Saturation-Intensity schemes for the multispectral images. The multispectral image is reconstructed from the HueSaturation schemes and the intensity scheme is replaced by the TM8 panchromatic band. The resulting sharpened image combines the spatial resolution of the panchromatic the Puyo plateau and covers $51400 \mathrm{~km}^{2}$, which is an area band $(\sim 15 \mathrm{~m})$ with the radiometric characteristics of the 30 much larger than that of the catchment of the Rio Pastaza meter data, which allows the preservation of high $\left(13700 \mathrm{~km}^{2}\right.$, see above). The Pastaza megafan appears as a frequency details.

marked topographic high within the Amazonian plain. In

MrSID Landsat 5 images have a lower resolution of this respect, it is similar to the smaller-sized megafans around $30 \mathrm{~m}$. The mosaic corresponds to 78 images with a identified in the Bolivian piedmont (Horton and DeCelles period ranging from 1986 to 1994 (Table 1). 2001), and differs from most of the distributary areas of the

For detection of soil moisture and vegetation Amazonian lowlands such as the Rio Beni plain in Bolivia changes we used ASTER images that have higher (Dumont 1996) which are depressed areas.

accuracy. This sensor acquires four bands on VNIR

The modern megafan complex is bounded by the Rio spectral domain, 6 band on the short-wave infrared (SWIR) Mangosiza/Morona to the west, the upper Rio Tigre valley and 5 band on the Thermal domain (TIR). The spatial and the Iquitos arch to the northeast, and the Rio Marañon resolution of the sensor decrease with the wavelength: $15 \mathrm{~m}$ to the south (Fig. 1). This megafan is formed by the lefton VNIR domain, 30m on SWIR and $90 \mathrm{~m}$ in thermal bank tributaries of the Rio Mangosiza/Morona, the lower domain. As for Landsat 7 image, the SWIR and TIR Pastaza basin, the lower Corrientes and lowermost Tigre resolution was improved using the same process of image basin (downstream of the Tigre - Corrientes confluence), sharpening using high spatial resolution of VNIR bands and the tributaries to the Rio Marañon situated in the (i.e. $15 \mathrm{~m}$ ).

The spectral response of vegetation is characterized by triangle between the Pastaza and Tigre/Corrientes basins.

The apex of the megafan complex is situated at the a high reflectance level in the near-infrared region (NIR debouchement of the Rio Pastaza from the Puyo plateau from 700 to $1400 \mathrm{~nm}$, Baret and Guyot 1991). In western (Fig. 1). The proximal part of the fan has a $3 \mathrm{~m} . \mathrm{km}^{-1} \mathrm{mean}$ Amazonia, botanical studies have determined that changes slope whereas, in the same area, the Rio Pastaza has a in the abundance of vegetation (palm flora) are related to lower slope of $2 \mathrm{~m} \cdot \mathrm{km}^{-1}$ (C in Fig. 4). There, the Rio topography and soil drainage conditions (Montufar and Pastaza has an overall NW-SE direction and exhibits a Pintaud, 2006).

Vegetational changes are organized in very bright, front of the Cutucu dome (Cangaime anticline), all the more or less sinuous, bands, $\sim 1$ kilometre-wide and 10 to streams between the Rios Mangosiza and Cangaime, either 100 kilometres long like those shown in Figure 3. These tributaries to the Pastaza or to the Mangosiza/ Morona, narrow and sinuous bands are interpreted as abandoned exhibit a more or less accentuated curved pattern. This streams along which vegetation is absent or recent. The region will be termed hereafter Mangosiza-Cangaime area absence or the recent development of vegetation may be a (MCA), (Fig.1, 2 and 4).

result of the recent abandonment. Vegetational changes may have also been caused by changes in the draining properties of soils due to the presence of coarser-grained sedimentary bodies such as channels and alluvial ridges.

We used also radar images which have interesting capabilities of vegetation penetration of the microwaves to south will be termed he Rio Pastaza from southeast This penetration capability increased with the wavelength, the Rio Pastaza" (GDP), (Fig.1 and 8)

in our studied area ground penetration can not occur due to

In this middle megafan complex, three regions may be soil moisture. In some case, when the gallery forest covers distinguished. In the southwest, a parallelogram-shaped abandoned channels we used JERS radar images which abandoned megafan well-apparent in the Landsat images 
constitutes the present day drainage divide between the into adjacent ones ( 2 on Fig. 3A) as frequently observed in Morona and Pastaza basins (Fig.1). This region will be alluvial megafans (e.g. Wells and Dorr, 1987, in the Kosi termed hereafter Morona Pastaza Area (MPA). In the megafan). True rejoining channels (i.e., channels rejoining southeast, another system, partly abandoned, includes the those channels from which they diverged see Slingerland present-day lower Corrientes /Tigre basins. This region and Smith, 2004) are rare. 44 avulsion sites involving two will be termed Tigre-Corrientes area (TCA). Between the recently abandoned reaches or involving recently MPA and the TCA, a large WNW-ESE-trending abandoned abandoned and presently active reaches have been flood plain join the upper southeast-flowing reach of the numbered in the MPA (Fig. 3). Avulsion sites between Rio Pastaza to the Rio Corrientes. This area will be termed older reaches or difficult to locate are mapped as 'supposed Pastaza-Corrientes transition band (PCTB). The NW-SE avulsion sites'. 12 of these 'supposed' avulsion sites have section of the modern Pastaza valley having the same been numbered in the MPA.

direction as this abandoned floodplain and showing similar In the south where slopes are shallower, abandoned alluvial ridges is to be included in the PCTB. diverging/rejoining channels forming anastomosed patterns

The distal part of the megafan complex consists in a are observed, in particular the lowermost Pastaza River. huge floodplain made of swamps, forested areas and open Swampy areas are frequent in this area except a water areas with a very low regional slope $\left(0.3 \mathrm{~m} \cdot \mathrm{km}^{-1}\right)$ topographically higher triangular plateau close to the and river slope $\left(0.2 \mathrm{~m} \cdot \mathrm{km}^{-1}\right)$. In this distal fan part the Rio Pastaza-Marañon confluence representing a remnant of the Pastaza exhibits an anastomosing pattern (Fig. 4, reach E). Villano surface.

Its course is there markedly oblique to the general stream direction which is south-southeast to southeast. The lower order streams form anastomosed channels but remnants of former meandering reaches are frequently observed.

\section{5 - Avulsions in the Pastaza Megafan complex}

Numerous avulsions have been recognized in the different areas defined in the modern Pastaza fan (Figs. 2).

\section{1 - Avulsion relics in the MPA}

The MPA corresponds to the elongated abandoned megafan now forming the drainage divide between the Morona and Pastaza basins well apparent in the satellite images. The active streams that reoccupied some of the abandoned channels are still arranged as a low angle distributary pattern rising from the megafan ridge. The area of the abandoned alluvial fan is $\sim 13,750 \mathrm{~km}^{2}$, greater than
the well-known Kosi megafan, northern India, which is the well-known Kosi megafan, northern India, which is
only $\sim 10,000 \mathrm{~km}^{2}$. Volume estimate by means of an integration of transverse profiles yields a minimum value the of $140 \mathrm{~km}^{3}$. The MPA fan apex is situated in the northnorthwest, at $\sim 30 \mathrm{~km}$ to the south of the modern Rio in Pastaza in the area then occupied by the curved streams of

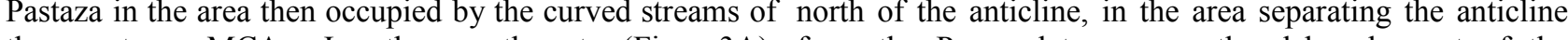
the eastern MCA. In the northwest (Fig. 3A), from the Puyo plateau, near the debouchement of the paleochannels are amalgamated and difficult to distinguish Pastaza. Several abandoned paths of the Rio Pastaza have in Landsat images and SRTM DEM unless where re- been recognized in this area. Path \#1 (Fig 6A and B) occupied by active streams. There, alluvial ridges appear appears as a gentle convex to east curve parallel to the quite rectilinear (3 on Fig. 3A). Meander loops are visible anticlinal front. This path is the oldest one, for it joins the ( 2 on Fig. 3A) but their sinuosity is moderate ( 2 in Fig. highest terrace on the right bank of the Rio Pastaza. Its $3 \mathrm{~A})$ and constant over the whole area $(\mathrm{S} \sim 1.2)$.

uppermost part cut the nose of the Cangaime fold through

In the median part of the MPA fan (3 on Fig. 3A), the a water gap. This water gap is abandoned at the junction paleochannels are not amalgamated and the morphology of with the upper terrace where it is prolonged by a wind gap. alluvial ridges is much easier to characterize. Ancient Path \# 1, except its uppermost part (the wind gap) is now streams display sub-parallel patterns and are frequently reoccupied by the Rio Macuma which comes from the reoccupied by right bank tributaries of the modern Pastaza Eastern Cordillera after having formed a $180^{\circ}$ loop at the and the left-bank tributaries of the modern Rio Morona tip of the western Cutucu dome (Bès de Berc, 2003). Path (Fig. 1 and 3C). Three types of reaches may be observed: \#2 (Fig. 6) leaves path \#1 immediately to the south (Fig. (1) ancient reaches characterised by a reduced contrast $6 \mathrm{~A}$ ) and forms a tighter valley rejoining path $\# 1 \sim 30 \mathrm{~km}$ between the valley and the forested floodplain; (2) recently downstream. Path \#3 is derived from path 1 through an abandoned reaches with a marked contrast between valley avulsion site located upstream of the 1-2 site (a in Fig. and floodplain; (3) abandoned reaches re-annexed, entirely 6A). Another avulsive branch leaves path \# 2 at point b to or partly, by present-day rivers. These channels/alluvial follow a new course which corresponds to a section of the ridges have a moderate sinuosity (but the modern streams present-day Rio Pastaza flowing toward the east-southeast that reoccupy these channels are much more sinuous), (path \#4). Near point c, another abandoned stream is diverging channels are frequent and may have switched observed connecting the Pastaza and path \#3 (path \# 4). 
The present course of the Pastaza toward the southeast appearing in a bright light green to form a convex(path \# 5) thus appears as a result of the last avulsion. In westward curve flowing close to the abandoned channel any event, avulsion 4 (point c) was younger than avulsions without rejoining it. In both cases, the Pastaza thus 1 to 3, for the bifurcation between paths \#4 and \#5 is appears as having incised through its proper valley to observed on a lower terrace. Paths \# 1, \# 4, and \# 5 follow achieve the avulsion (avulsion by incision after Slingerland meandering valleys whereas path \# 3 forms a low sinuosity and Smith, 2004). It should be pointed out that downstream valley. This low sinuosity valley contrasts with the high of the PCTB, the DEM profiles and the presence of sinuosity and the low amplitude of the meander loops of swampy areas on both sides of the river bed indicate that the underfit stream which reoccupied it. No wide valley the Rio Pastaza exhausted its bed instead of incising it as in seems to have been ever formed by path \# 2 but a series of the north. This uplift of the Pastaza has for effect to curved tributaries is observed in LANDSAT images separate the eastern portions of previous southeast-flowing suggesting repeated partial avulsions giving rise to short- rivers now dying out into the swampy fringes of the right lived avulsive streams. The wide meanders of path \# 4 side of the Pastaza alluvial ridge from their western having amplitude and bed width of the same order of counterpart now rising from the swamps of the left side of magnitude as the present channel but higher sinuosity are this ridge.

well apparent in the LANDSAT images and the SRTM DEM at the vicinity $(\sim 8 \mathrm{~km})$ of the present course of the Pastaza (path \# 5). Meander mosaics preserving preferentially meander loops convex to the west are observed locally in the west of path \# 4 whereas a vegetated band free of meander (Fig. 1) remnants separates path \# 4 and path \# 5 (the present Rio Pastaza).

\section{4-Avulsions in the TCA}

The TCA is composed of two parts. The northern part (upper and middle Corrientes) shows distributary / rejoining alluvial ridges settled in a wide (up to $\sim 70 \mathrm{~km}$ ) floodplain, giving rise to anastomosing channels which characterize partial avulsions (see definitions and terminology in Slingerland and Smith, 2004). The modern

5.3 - The avulsions in the PCTB and the Great and ancient alluvial ridges are distinguished by contrasted Diversion of the Pastaza spectral responses as shown by the example of the Rio

Landsat images and the transverse profiles extracted Corrientes at the vicinity of the north-eastern boundary of from the SRTM DEM (Fig. 5) show that a large WNW- the area (Fig. 3B). Abandoned alluvial ridges (1 and 2 in ESE-trending abandoned valley joins the upper southeast- Fig. 3B) have in general a brighter response and sharp flowing reach of the Rio Pastaza to the Rio Corrientes in boundaries strongly suggesting that vegetation was continuation of the Pastaza valley. Downstream, i.e., south younger, and therefore that the avulsions were younger, of the GDP (Fig. 2 and 7), the Pastaza valley narrows than in the MPA. The abandoned channels, however, have significantly, which confirms the abandon of the former a more or less bright green response (indicating a more or wide valley which assured the transition between the less recent vegetation growth) which can be interpreted as MPA/MCA and the TCA. As in the northern TCA, a a succession of abandonments and avulsions. The alluvial succession of avulsions and channel rejoinings formed ridges in the TCA are linear as in the MPA but the anastomosed channel patterns, now abandoned, in the sinuosity of the ancient channels seems to have been present Pastaza floodplain as well as in the Pastaza- higher $(\sim 1.7)$. Recent meandering streams such as the Corrientes abandoned valley. The multi-channel pattern modern Rio Corrientes may reoccupy the larger abandoned shown by the present-day Pastaza in this area (downstream channels (3 in Fig. 3B). 18 avulsions sites have been of the GDP) may represent the last expression of this numbered in this northern part of the TCA. In the middle process. Therefore, the PCTB, including the NW-SE reach part of the TCA two avulsion belts may be distinguished: of the Pastaza can be considered as an avulsion belt the lowermost Rio Corrientes belt trending west-east in the (Slingerland and Smith, 2004). It is worth nothing that the northeast and the Cuinico belt trending northwest multi-channel pattern of the Pastaza disappears southeast in the southwest.

downstream of the abandon and the Rio Pastaza resumes a The southern part of the TCA is fan shaped showing meandering course for an along-valley distance of more modern and ancient distributaries joining the Rio Marañon than $150 \mathrm{~km}$.

or the lowermost Rio Tigre. Landsat images show two

In the east of the PCTB, 8 avulsion sites including the 4 interfering fans well apparent in the arrangement and shape ones having led to the present-day course of the Pastaza of the numerous swamps of this region (Fig. 1). This have been defined. In the west, 7 avulsion sites have been pattern is less obvious, however, when only the alluvial defined. The present southward bend of the Pastaza (GDP) ridges and well defined channels are considered (Figs. 1 resulted from the last of these avulsions (Fig. 1).

Immediately downstream GDP, the 1990 Landsat parallel, even though more sinuous channels are observed image (Fig.1) shows an oxbow-shaped swampy area in the upper part. Well-characterized avulsions are less appearing in a blue-green colour in the outer arc of the frequent than in the north ( 9 avulsion sites) even though present-day bend, in geometrical continuity with the some of the channels are anastomosed.

abandoned valley. This feature, less apparent in the 2000 image, suggests an ancient left-hand open curve cut 6-Chronology, age and frequency of avulsions

through by the Pastaza. The SRTM DEM indicates that the The observations above may arrive to a relative bottom of the present Pastaza valley is there lower than the chronology of the major avulsions. The radiocarbon ages swampy area. A similar though smaller-sized feature is available in the literature (Räsänen et al. 1992; Räsänen et observed $25 \mathrm{~km}$ to the south (Fig.1). There, the present al. 1990; Bes de Berc et al. 2005) help us to constrain the Pastaza channel diverged from a convex-eastward loop ages of the avulsions in the areas of the Megafan. In the 
entire Pastaza megafan complex, 108 avulsion sites have 9200 \pm 200 Cal. years BP and $8480 \pm 110$ Cal. years BP, The been identified, representing an avulsion frequency of last avulsion to occur in the PCTB was the diversion to the $0.51 \pm 0.06 / 100$ years and an average recurrence time of south of the Pastaza "Great Diversion" leading to the $\sim 200$ years $(196 \pm 2$ yrs and $240 \pm 3$ yrs if we except the abandon of the eastern PCTB and the TCA (Fig. 8D). As a 'supposed' avulsion sites) (Table 2). However, as shown consequence, Avulsions in the eastern PCTB are supposed above, the type and origin of avulsions are quite different to have occurred after the last avulsions in the TCA ( in the areas we have distinguished and this value is only $8480 \pm 110$ Cal. years BP). The overall present-day course indicative.

(and thus the "great diversion") of the Pastaza is figurate in a map published in 1691 (Samuel Fritz map reproduced by

6.1 - Avulsions in the MCA/MPA and western PCTB Gomez 1994), indicating that the "Great Diversion" was The first entity to have developed was the MPA older than AD 1691.

megafan (Fig. 8A) where the channels, though re-annexed, In the TCA and the eastern PCTB, 26 avulsion sites were abandoned a long time ago as shown by their have been numbered. If the date of $8480 \pm 110$ cal. years BP subdued spectral response. The brighter spectral response was that of the first occupation of the eastern PCTB and of the abandoned channels in the TCA indicates that the TCA and the date of 1691 AD that of the last avulsion, the abandon was younger than in the MPA. This is confirmed avulsion frequency were $\sim 0.31 / 100$ years and the by the fact that the eastward avulsions in the MCA from recurrence time reduces to $\sim 350$ years ( $342 \pm 5$ years for all which originated the channels of the PCTB area and the sites to $391 \pm 6$ years accepting the 'supposed' sites). If the TCA derived from the southward-flowing paleo-Pastaza age of first occupation of the eastern PCTB and TCA were which fed the MPA megafan. The curved streams of the $9200 \pm 200 \mathrm{Cal}$ yrs BP, then the average frequency of MCA appear to be superimposed on the apex of the MPA avulsions were $0.29 / 100$ years and the time of recurrence megafan and can be thus considered to be younger. In were $\sim 400$ years $(372 \pm 9$ yrs for all sites and $426 \pm 10$ yrs terms of ages, the apex of the MPA megafan being situated excepting the 'supposed' sites).

at the debouchement of the Rio Pastaza from the Puyo

The present day activity of the underfit streams plateau, the formation of this megafan and the avulsions reoccupying the pre-existing channels of the TCA is due to therein are younger than the diversion of the Pastaza in the the fact that these streams have been re-alimented by Puyo plateau. This diversion being a result of arching and streams newly formed in the upper Villano surface in front backtilting of the plateau surface (Mera surface), the MPA of the Puyo landslides (including the Rios Tigre and megafan was younger than $17,920 \pm 100{ }^{14} \mathrm{C}$ years BP (Bes Corrientes, Bès de Berc et al., 2005). The relatively recent de Berc et al., 2005), or $21,160 \pm 260$ cal. years BP age of the Pastaza "Great Diversion" is also attested by the according to Reimer et al.'s( 2004) IntCal calibration. beheading of the SW-flowing rivers formed after the

The relative chronology between the MCA and the abandon of the MPA megafan.

PCTB avulsions is less easy to establish. However, if we take into account the chronology of avulsions and the outward progression of the curved stream network pattern in the MCA on one hand and the chronology of avulsions

\section{3 - Significance of frequencies}

The frequencies and average recurrence times of the in the significant because of in the similarity of the last diversion in the MCA corresponds to the first diversion avulsion features. In contrast, the avulsions older than the in the PCTB (Fig. 8B). Therefore, one can consider that the occupation of the TCA floodplain formed in at least 3 avulsions in the MCA are older than those in the TCA. differing contexts: construction of an alluvial megafan Ages of $9200 \pm 200 \mathrm{yrs}$ and $8480 \pm 110 \mathrm{Cal}$ yrs BP have been (MPA), piedmont of a propagating thrust-related fold obtained by (Räsänen et al. 1992) in the floodplain of the (MCA), and construction of an avulsion belt (PCTB). Rio Corrientes in the northern TCA. The development of Therefore, it is likely that the mean recurrence time varied this floodplain being a result of the avulsions at the origin from one area to another, and the average time of $\sim 350$ of the TCA, the abandon of the MPA was older than years can be considered as an order of magnitude. $9200 \pm 200 y r s$ Cal yrs BP.

If we group the avulsions older than the first 7-Discussion occupation of the TCA floodplain, i.e., those in the MPA, the MCA, and the PCTB, 84 avulsion sites have been defined, including 17 'supposed' sites. If the date of $8480 \pm 110$ Cal. years BP is considered as the age of the first occupation, then the frequency is $\sim 0.66 \pm 0.2 / 100$ years and the recurrence time is $\sim 150$ years ( $142 \pm 6$ years accepting all sites and $179 \pm 7$ years excepting the period of 'supposed' sites). Assuming a first occupation age of Because our study cannot provide neither avulsion duration $9200 \pm 200 \mathrm{Cal}$. years BP, the frequency is $\sim 0.7 / 100$ years nor the number of coeval avulsions, interavulsion periods and the recurrence time is $\sim 170$ years $(151 \pm 4 \mathrm{yrs}$ cannot be determined and the recurrence time referred to in accepting all sites and $189 \pm 6$ yrs excepting the 'supposed the present paper assumes 'instantaneous' avulsions. sites').

\section{1 - Avulsion frequency}

Data relating to avulsions frequency exist for a few modern rivers in various contexts including avulsion belts, megafans, and deltas. Stouthamer and Berendsen (2001, table 2) present such data as interavulsion periods (= 6.2 - Avulsion in the TCA, eastern PCTB and modern Pastaza Average frequencies (= total number of avulsions having occurred during a given period divided by the duration of avulsions have been preferred in the following discussion. As shown above, avulsions in the TCA occurred around Table 3 presents average frequencies in the areas 
considered by Stouthamer and Berendsen (2001) to which third group involves a reduction in the capacity of a have been added the Brahmaputra River (Bristow, 1999) channel to convey all of the water and sediment delivered and the Taquari megafan (Assine, 2005). to it. The fourth group involves other processes than those

The average avulsion frequency of $0.51 / 100$ years for of groups 1 to 3, as various as animal trails and stream the whole Pastaza megafan complex is of the same order of capture. In the context of the Amazonian basin, the group 4 magnitude as for the Rhine-Meuse delta $(0.88 / 100$ cal processes are precluded or unlikely. Intrinsic processes years, Stouthamer and Berendsen, 2001) but much less related to sedimentation and extrinsic (external) processes than for the Lower Brahmaputra River (3.47, Bristow, are involved in any of the groups 1 to 3. External processes 1999), the Kosi megafan (4.88, Gole and Chitale, 1966), or such as tectonic uplift/subsidence or lateral tilting are the Taquari megafan ( 10, Assine, 2005) which have, thought by Jones and Schumm (1999) to be capable of however, been observed during much shorter periods of causing (and not only triggering) avulsion. Slingerland and time (202, 246, and 30 years, respectively, see Table). In Smith (2004) used a theoretical stability analysis of contrast, this avulsion frequency of $0.51 / 100$ years is bifurcating channels and a thorough review of the papers greater than those of the Saskatchewan River $(0.17$, dealing with the style and frequency of avulsions. They Morozova and Smith, 1999, 2000), the Po River (0.25, concluded that avulsion frequency increases with Nelson 1970 in Mackey and Bridge, 1995) or the Yellow increasing aggradation whatever the exact cause of River (0.21, Li and Finlayson, 1993). aggradation and the trigger (even though the authors

When considering the different entities constituting the acknowledged that avulsions may occur in the case of Pastaza megafan complex, the western domain formed by limited or no aggradation). According to them, avulsions the MPA, the MCA, and the western PCTB records a are promoted by rapid alluviation of the main channel, a higher avulsion frequency ( 0.6-0.7) than the eastern wide unobstructed floodplain able to drain down-valley, domain ( $(0.3)$. The former value is probably and frequently recurring floods of high magnitude. underestimated because many older channels in the MPA According to this viewpoint, it should be appealing in a are likely to have been masked by the large aggradation megafan to distinguish between causes and triggers of having occurred in this area. A comparison between the avulsions. In this case, the cause should be the huge MPA megafan and the other megafans (Kosi, Taquari) is amount of sediment transported into the megafan (see e.g. difficult because we have no age for the MPA alone and the Wells and Dorr, 1987, or Leier et al., 2005), and the trigger situation or geometry of these megafans differs markedly. should be "opportunistic" (Slingerland and Smith, 2004), The Kosi megafan appears as a piedmont megafan like the intrinsic (e.g. high floods) as well as extrinsic (e.g. MPA but it is very flat compared with the MPA and is tectonics). Accordingly, only the cause of the high affected by a monsoonal climate. This may allow the sedimentary load should be researched as the cause of the mechanism proposed by Wells and Dorr (1987) to operate avulsions in the entire modern Pastaza megafan complex, in this megafan and not in the more bulging MPA, thus tectonic events being considered as opportunistic triggers. explaining the much higher avulsion frequency in the However, Jones and Schumm (1999, their table 1) consider former. In fact, the avulsion frequency in the MPA is the tectonics as a cause as well as a trigger of avulsion because closest to that in the Rhine-Meuse delta which has formed tectonic uplift may decrease channel slope or increase the in a much different context but is closely controlled by slope of the potential avulsion course as this is obvious in aggradation (Stouthamer and Berendsen, 2000, 2001). the case of piggy back basins formed upstream of growing

The value obtained in the PCTB-northern PCA anticlines (see e.g. Burbank et al., 1996; Burbank and floodplain avulsion belt is very close to those obtained in Anderson, 2001 p. 194; Humphrey and Konrad, 2000; van floodplain avulsion belts having similar areas der Beek et al., 2002). This is less obvious in the case of (Saskatchewan and Po Rivers) or much larger areas small relative increases in elevation such as those in front (Yellow River) during similar spans of time but much of the Cangaime anticline (see, however, Bridge and lower than in the Brahmaputra floodplain, which has, Leeder, 1979; Alexander and Leeder, 1987; Dumont and however, been observed during a much shorter period. This Hanagarth, 1993) and this point will be discussed hereafter suggests that the avulsions forming avulsion belts in low in each of the studied areas.

gradient floodplains might have similar long-term average Styles of avulsions as defined by Slingerland and Smith frequencies, but highly varying short-term average characterize 3 different ways by which avulsions are frequencies. In this respect, floodplain avulsion belts achieved in the floodplain: (a) avulsion by annexation by should be similar to deltas such as the Rhine-Meuse where which an existing channel is appropriated or reoccupied; avulsion frequency varies in the time from 2.43 between (b) avulsion by incision, where new channels are scoured 8000 and 7300 cal years BP to 0.85 between 7300 and into the floodplain surface; and (c) avulsions by 3200 cal years BP (Stouthamer and Berendsen, 2001).

\section{2 - Style, local causes and triggers of avulsions in} the Pastaza megafan complex

The origin of avulsions have been thoroughly discussed by Jones and Schumm (1999) and Singerland and Smith (2004) in their reviews of river avulsions.

progradation, characterized by extensive deposition and multi-channeled distributive networks. Jones and Schumm (1999) consider 4 groups of causes volume of sediment forming this megafan has been and eventually triggers of avulsion. The first two groups sufficient for the fan crest to constitute the divide between involve an increase of the ratio of the slope of the potential the Morona and Pastaza drainage basins until today, long avulsion course to the slope of the existing channels. The after the abandon. In spite of the surimposition of the MCA 
over its very apical part, the organisation of the megafan is Mera at $60 \mathrm{~km}$ from the volcano (Bès de Berc et al., 2005). well apparent in satellital images. As in other megafans Therefore the Sangay II collapse could hardly have caused having a moderate average slope such as the Kosi megafan the abandon of the MPA megafan and it is unlikely that it in the Himalayan piedmont (Gole and Chitale, 1966; Wells might be a direct cause or trigger of the avulsions. and Dorr, 1987), large aggradation occurred and avulsions However, the gradual erosion and transport in the fluvial associating progradation and annexation predominate as system of the huge quantity of material provided by the suggested by the high amount of sediment distributed in volcanic eruptions coeval with, or older than, the MPA the megafan and the multi-channeled distributive network. might have constituted a large part of thematerial The switch of a channel into an adjacent one (which must accumulated in this area.

not be confused with diverging/rejoining channels, see Wells and Dorr, 1987, fig. 2) can be interpreted as in the Kosi megafan (Wells and Dorr, 1987) as evidence of the lateral shifting of a single channel sweeping across the fan. Wells and Dorr (1987) interpreted the avulsions at the occ origin of the shifting of the Kosi River as results of not only river migration but also avulsions have been overflow of both highly aggraded active rivers (alluvial controlled, at least in part, by tectonics. The local curved ridges) and less aggraded pre-existing non-active or less courses of rivers otherwise flowing south along the active rivers in the inter-ridges areas, promoting drainage regional slope show that these rivers adapt locally to the into the topographic lows at the cessation of flooding. No new domal topography created by the propagation of the unusually large floods have been recorded in the upper thrust-fold structure. The divergences at the origin of the Amazonian basin in the historical period which is probably successive paths, the clear separation between them, and more humid than the early Holocene when the MPA the scarceness of meander mosaics (except locally in the formed (see Weng et al., 2002). This constitutes a west of path \# 4 in Fig. 2) suggest that avulsion was there a difference with the Kosi fan where huge floods have been more efficient process than progressive shifting to achieve recorded in the modern and recent times. In fact, Wells and this adaptation, even though progressive shifting may have Dorr (1987) demonstrated in the Kosi fan that major locally occurred. At point A in Fig. 3, the avulsion from avulsions were not correlated with unusually high floods of path \#1 (Fig. 2) to path \#2 (Fig.2) is clearly a result of the any origin but were a result of 'normal' floods. However, lateral propagation of the Cangaime fold defeating path \#1 'normal' floods in the Kosi cover very large areas because and transforming the water gap passing through the nose of of the very flat topography of the fan. The MPA fan is the fold into a wind gap. In this case, fold growth is the more bulged than the Kosi fan and the precipitation regime major if not the unique cause of the avulsion (if a pure is not monsoonal. Therefore, wide annual floods are more "mechanical" diversion like this one can be actually difficult to invoke as triggers of avulsions in the MPA than considered as a diversion). This is not the same for the in the Kosi system and the absence of wide annual floods other avulsions of the MCA. LANDSAT images of the like those occurring in the Kosi might explain the much streams affected by these avulsions indicate deposition lower frequency of avulsion in the MPA. along the valleys but the topographic sections normal to

Other causes/triggers of avulsion in the MPA might be the rivers show V-shaped incised valleys with no evidence tectonics and volcanism. An influence of tectonics on of levees or exhausted beds which could have shown that avulsions is here rather unlikely because the MPA is aggradation was the direct cause of avulsion. It might be relatively far from the active Subandean Frontal Trust and objected that these V-shaped valleys have been incised by the Cutucu/Cangaime thrust-fold dome, and earthquakes the rivers having reoccupied the abandoned valleys, but it recorded in the Amazonian domain are deep events with a is unlikely that the abandoned alluvial ridges would have relatively low magnitude.

been entirely removed as a result of incision by underfit

The large-scale volcanic eruptions eventually capable streams. Therefore, even though the sedimentary/water of influencing the hydrologic regime of the Pastaza system discharges were probably as large as in the other parts of when the MPA was active were a large rhyolitic eruption of the Pastaza megafan complex, tectonic uplift resulting the Cotopaxi, the first pyroclastic flows and associated from the lateral/frontal propagation of the Cangaime lahars of the Chimborazo at $8000-5400$ BC (Table ), and thrust-fold seems here to have been the direct cause of the the collapse of the Sangay II. Cotopaxi and Chimborazo avulsions. This interpretation is also supported by the volcanoes are far from the Amazonian domain and no localization of the avulsions near the northern nose of this traces of these events are found downstream of Baños in fold. Earthquakes such as the 1980 El Asnam (Algeria) the western Eastern Cordillera (Bès de Berc et al., 2005). earthquake (Philip and Meghraoui, 1983) capable of We have no information on the presence of products of the causing local rapid uplift of river beds could be possible Sangay II collapse in, and downstream of, the terraces of triggers. Because of the absence of levees to be breached, the Rio Palora. The uncertainty of the date of this event seismic shaking alone as invoked by e.g. Stouthamer and (>14,000 years BP, Monzier et al., 1999) does not assure Berendsen (2000) in the Rhine-Meuse delta, could hardly that it was contemporary with the construction of the MPA. be taken as a possible trigger in the MCA in spite of Even though it were so, the along-stream distance between markedly greater earthquake magnitudes. In contrast, the MPA and the crater $(\sim 180 \mathrm{~km})$ is very long when we intrinsic factors such as large floods may be considered as consider than the $8 \mathrm{~km}^{3}$ avalanche resulting from the 3000 possible triggers even in this tectonically active context years old collapse of the Tungarahua II travelled 'only' 21 because aggradation may have elevated the river bed $\mathrm{km}$ along the valley and that no traces of lahars following sufficiently for the flow to take advantage of the tectonic this event have been found in the Pastaza terraces near slope. 
be fed by temporary breaching of channel banks with short

7.2.3 - The avulsions in the PCTB and the new channels being formed (Stanistreet et al., 1993). The northern TCA.

predominance of low sinuosity channels is also a

In the TCA and the PCTB no field observations of characteristic common to the southern TCA and the avulsion features are available and satellite images only Okavango fan. We have no evidence in the southern TCA provide information on the size and arrangement of that channels are confined by vegetated and/or peat levees channels. However, the principal characteristic of these but no more evidence that they are not, and the similarity areas is the presence of diverted/rejoining channels between the southern TCA and other very shallow humid forming anastomosing patterns still apparent in spite of fan such as the Okavango or the Taquari suggest that they vegetation growth. This suggests sustained avulsive flow might be.

transforming a floodplain into an avulsion belt showing abandoned anastomosed channels and small isolated flood basins as in the modern Saskatchewan River (Morozova and Smith, 2000; Slingerland and Smith, 2004) or other

\section{Pastaza megafan complex}

7.3 - Remote causes of the avulsions in the

As discussed above, aggradation played a major role in avulsion belts formed under various climatic regimes (e.g. the generation of avulsions in the different areas studied in Schumm et al., 1996; Smith et al., 1997; Bristow, 1999; the present paper, even in the MCA where tectonics Ethridge et al., 1999; and other refs in Slingerland and prevails. This conclusion agrees with that of many authors Smith, 2004). According to Slingerland and Smith's (2004) having studied avulsions in various contexts, scale, and review, anastomosing reaches are results of progradational time lapses (see refs above). The origin of this large avulsions (Morozova and Smith, 2000) characterized by aggradation as a remote cause of avulsion is crucial in the deposition out of the parent channel into the invaded Pastaza megafan complex where the catchment area floodplain and favoured by slow runoff promoted by low $\left(13,700 \mathrm{~km}^{2}\right)$ is much smaller than the depositional area floodplain slopes (Slingerland and Smith, 2004, p. 264). (51,400 $\left.\mathrm{km}^{2}\right)$. Table 2 shows characteristics of piedmont The meandering streams occupying alluvial ridges such as megafans in the Bolivian Andes (Rio Grande, Rio the middle Rio Corrientes could be the new dominant Pilcamayo, and Rio Parapeti, after Horton and DeCelles, meandering channel constituting the outcome of the 2001) and of the Kosi megafan compared with the Pastaza evolution of the avulsion belt (fig. 2 in Slingerland and megafan complex. These characteristics include catchment Smith, 2004). In most of the modern avulsion belts such and fan surfaces, fan/catchment ratio, water discharge, the Saskatchewan River (Morozova and Smith, 2000), the stream power per length unit, and incision rate. The entire Niobrara River (Ethridge et al., 1999), the Ovens and King Pastaza megafan complex has a much greater fan / rivers, Australia (Schumm et al., 1996) or the Brahmaputra catchment ratio (3.75 instead of 0.72 for the Rio Parapeti River (Bristow, 1999), the causes of avulsions are entirely and 0.20-0.30 for the other systems). The contrast between autocyclic and related to the high sedimentary discharge the Pastaza megafan and the other megafans reduces if we and deposition of these rivers even though the trigger was consider only the MPA which is the first entity to have occasionally extrinsic (e.g. damming as for the Niobrara been formed and was abandoned when the eastern entities River, Ethridge et al., 1999). However, for Smith et al. formed. If so, the fan / catchment ratio reduces to 1, which (1997), neotectonic movement is the underlying cause of remains much higher than the other systems having similar avulsion and anastomosis in the panhandle (upper entry stream powers per unit length. If we consider that the corridor) of the Okavango fan situated in a 'relative' valley surface of the megafan is proportional to the volume of gradient depression inferred to represent a small graben. In sediments preserved, then the volume of sediment the case of the PCTB and TCA, the avulsion belt is situated transported per unit stream length was much greater for the much too far from the active tectonic region, and the Rio Pastaza than for the other systems presented in Table earthquake foci are too deep and their magnitude too low 2. Table 2 also shows that the Rio Parapeti which has a for tectonics to be the cause or trigger of the avulsions. For catchment surface close to that of the Rio Pastaza has a the same reasons as in the MPA, and notably the great lower streampower and formed a much smaller fan, which distance to the volcanoes, volcanic eruptions, although would suggest that streampower is determinant in the frequent at the time when the PCTB and the MCA formed construction of the fan. However, a comparison between (see Table 1), cannot have been a direct cause or trigger of the MPA and the Kosi indicate that the ratio of the avulsion in these areas.

\section{surrounding areas.}

catchment surfaces MPA / Kosi is 0.26 whereas the ratio of the fan surfaces MPA/Kosi is $\sim 1.14$. This means that the have been 4 times greater in the Pastaza catchment than in In the southern part of the TCA the fan shape is the Kosi catchment whereas the streampower of the Kosi essentially apparent in the arrangement and shape of the River is twice that of the Pastaza. Now, if we compare the numerous swamps of this region (Fig. 1). Well- average values of incision rates for the Sun Kosi and Arun characterized avulsions are rare. The style, cause, and rivers (the junction of which gives birth to the Kosi river) triggers of avulsions seem to be researched in the very in the Main Boundary Thrust - which are of $1.5-2.5$ shallow attitude of the topography like in the 'losimean' mm.yr' (Lavé and Avouac 2001) - with those for the megafans (Stanistreet and McCarthy, 1993) such as the Pastaza in the Eastern Cordillera - which are of $\sim 4-5$ Okavango (Stanistreet and Mc Carthy, 1993; Stanistreet et $\mathrm{mm}^{-1} \mathrm{y}^{-1}$ (Bès de Berc et al., 2005) - , it appears that the al., 1993) or the Taquari (Assine 2005; Assine and Soares incision rates in the Pastaza are twice those in the Kosi. 2004). In fact, the arrangement and shape of the swamps is Because the streampower is twice lower in the Rio Pastaza likely to reflect the configuration of the floodplain and may than in the Kosi River, it is likely that the faster incision 
rate in the Pastaza do reflect the rate of uplift of the progradational avulsions in all the studied areas except the Eastern Cordillera combined with a rapid adaptation of the MCA could be taken as evidence that the high sedimentary river profile (Bès de Berc et al., 2005). Another cause must load of the Pastaza system was the underlying cause of therefore be researched to the larger amount of material avulsion and and of the construction of very large input into the Pastaza system.

In their study of tropical megafans, Leier et al. (2005) emphasized the contrast between the peak of discharge and 8 -Conclusions the mean annual discharge, as a characteristic of all the

Remote sensing imagery mapping of the successive megafans. The Rio Pastaza, like many other equatorial channels of the Rio Pastaza enabled us to evidence 108 rivers (Latrubesse et al. 2007) does not display such a sites of avulsion in the Rio Pastaza megafan. The location contrast in hydrologic cycles. Even during ENSO events, of these sites, the available radiocarbon ages as well as the ratio peak of discharge / mean annual discharge remain historic maps of the $17^{\text {th }}$ century, allow us to propose an stable even though the mean annual discharge increases. evolution of the migration and avulsions of the Rio Pastaza Annual or episodic contrasts in hydrologic cycles are thus since the Last Glacial Maximum.

unable to explain the very large amount of sediment The first avulsions of the Rio Pastaza occurred after the deposited by a fluvial system having a relatively small LGM roughly parallel to the Subandean front and gave rise catchment. In any event, if this sediment were extracted by to a well defined fan-shaped distributary pattern (Fig. 9A). erosion from the bedrock of the catchment, this should In response to thrust-related anticline forelimb tilt, the Rio imply a very rapid denudation and uplift of the entire Pastaza and the apex of the megafan were progressively Eastern Cordillera and eastern Western Cordillera of shifted eastward until the "Great Diversion" of the Rio Ecuador during the late glacial period. The average Pastaza changed its course to the east-southeast towards denudation rate inferred by Vanacker et al. (2007) from the present-day Rios Tigre and Corrientes (TCA) (Fig.9B). their radionuclide studies in small basins of the eastern Around $9200 \pm 200$ or $8480 \pm 110$ Cal years BP, avulsions Cordillera is $0.2 \mathrm{~mm}_{\text {year }}{ }^{-1}$. This value is considered to be occurred in the TCA (Fig.9C). The Rio Pastaza abandoned high by these authors. However, such a denudation rate then its east-southeast course and the Tigre-Corrientes area acting during the 11,000 yrs of activity of the MPA would to follow its present-day southerly course. This last have provided only $\sim 30 \mathrm{~km} 3$ of material if we assume that avulsion was older than 1691AD (Fig. 9D).

the denudation rate was the same over the entire Pastaza The average recurrence time of avulsions in the basin (and less if the denudation rate was lower in the Marañon-Pastaza area, probably overestimated, ranges Interandean Depression as observed by Vanacker et al. between $142 \pm 6$ years and $189 \pm 6$ years whereas in the (2007). Moreover, the uplift rate of4-5 mm/year uplift Tigre-Corrientes areas, the average recurrence time of since the LGM observed by Bès de Berc et al. (2005) avulsions is underestimated and ranges from $342 \pm 5 y$ years to cannot be considered as a rapid uplift when values of $\sim 2$ 426 10 years.

$\mathrm{cm} /$ year have obtained in areas such as the Southern Alps Regional tectonics is active in the northwest of the of New Zealand). Volcanism may be another solution to Maranon-Pastaza area and responsible for thrust-related this problem. As discussed above, it is unlikely that anticline eastward forelimb tilt and lateral propagation is sedimentary pulses generated by volcanic eruption as believed to have controlled most of the avulsions in this previously proposed by Räsänen et al. (1990) were a direct area. No such tectonic control seems to have acted in the cause or trigger of avulsions in any of the areas studied south of the MPA and the TCA. The characteristics of the here. However, it is obvious that fluvial reworking of hydrologic cycles of the Rio Pastaza doe not allow volcanic material associated to runoff and local landsliding "hydrologic" driven avulsions such as those known in in the easily erodable volcanic deposits has input volcanic areas characterized by contrasted hydrologic cycles material into the system. However, the estimate of the total invoked by Leier et al. (2005) in other megafans. Climatic volume of material provided by the volcanoes is of about fluctuations or pulses in sedimentary fluxes, not clearly $20 \mathrm{~km}^{3}$ (see above). It should be pointed out that the related to volcanic activity as previously proposed by addition of the material provided by the volcanic eruption Räsänen et al. (1990), seem to be the most likely cause of and the denudation as inferred from the study of the avulsions in those areas.

cosmogenic radionuclides is only of $\sim 50 \mathrm{~km}^{3}$, which is small compared with the $\sim 140 \mathrm{~km} 3$ of the MPA.. In any Acknowledgements

event, it is likely that the heavy volcano-sedimentary and sedimentary load transported down to the Amazonian lowland promoted aggradation and then avulsions as soon as the slope decreased. Even where the local cause or trigger of avulsion was not aggradation (e.g. the MCA) aggradation promoted by the heavy volcano-sedimentary load made the channel close to the avulsion threshold (Jones and Schumm, 1999) such that any 'opportunistic' event (Slingerland and Smith, 2004) can trigger avulsion. Conversely, aggradation may have triggered avulsion in areas such as the northern MCA where tectonic tilting has created a lateral slope more favourable to the avulsive channel but where the parent channel is confined by incised walls. In another ground, the prevalence of

This study benefited of the logistic and financial support of the IRD (French Institute for Research in Development). This investigation was supported by a doctoral Alban fellowship ( $n^{\circ}$ E05D057404EC) and Université Toulouse III, Paul Sabatier grants.

\section{REFERENCES}

Alexander J and Leeder MR, 1987. Active tectonic control of alluvial architecture. In: F.G. Ethridge, R.M. Flores and M.D. Harvey (Eds.), Recent developments in fluvial sedimentology. Special Publication. SEPM (Society for Sedimentary Geology), pp. 243-252.

Assine ML, 2005. River avulsions on the Taquari megafan, Pantanal wetland, Brazil. Geomorphology, 70: 357-371.

Assine ML and Soares PC, 2004. Quaternary of the Pantanal, west-central Brazil. Quaternary International, 114: 23-34.

Autin WJ, Burns SF, Miller BJ, Saucier RT and Snead JL, 1991. Quaternary Geology of the Lower Mississipi Valley. In: R.B. 
Morrison (Ed.), Quaternary Nonglacial Geology: Conterminous U.S. Geology of North America. Geological Society of America, pp. 547582.

Baby P, Rivadeneira M, Christophoul F and Barragán R, 1999. Style and timing of deformation in the Oriente of Ecuador. In: Orstom (Ed.), 4th International Symposium of Andean Geodynamics. ORSTOM, Göttingen, pp. 68-72.

Barba D, Robin C, Samaniego P and Eissen J-P, 2008. Holocene recurrent explosive activity at chimborazo volcano (Ecuador). Journal of Volcanology and Geothermal Research, 176: 27-35.

Barberi F, Coltelli M, Ferrara G, Innocenti F, Navarro, J-M, Santacroce R, 1988. Plio-Quaternary volcanism in Ecuador. Geological Magazine, 125(1): $1-14$

Baret F and Guyot G, 1991. Potentials and limits of vegetation indices for LAI and APAR assessment. Remote Sensing of Environment, 35(161-173).

Barragann R, Baudino R and Marocco R, 1996. Geodynamic evolution of the Neogene intermontane Chota basin, Northern Andes of Ecuador. Journal of South American Earth Sciences, 9(5-6): 309-319.

Behling $\mathrm{H}$ and Hooghiemstra H, 1999. Environmental history of the Colombian savannas of the Llanos Orientales since the last glacial maximum from lake records El Pinal and Carimagua. Journal of Paleolimnology, 21: 461-476.

Behling $\mathrm{H}$ and Hooghiemstra H, 1998. Late quaternary palaeoecology and palaeoclimatology from pollen records of the savannas of the Llanos Orientales in Colombia. Palaeogeography Palaeoclimatology Palaeoecology, 139: 251- 265.

Bes de Berc S, Soula J-C, Baby P, Souris M, Christophoul F and Rosero M, 2005. Geomorphic evidence of active deformation and uplift in a modern continental wedge-top - foredeep transition: example of the eastern Ecuadorian Andes. Tectonophysics, 399(1-4): 351-380.

Blair TC and McPherson JG, 1992. The Trolheim fan and facies model revisited. Geological Society of America Bulletin, 104(6): 762-769.

Bourdon E, Eissen J-P, Gutscher MA, Monzier M, Hall ML, Cotten J, 2003. Magmatic response to early aseismic ridge subduction: the Ecuadorian margin case (South America). Earth and Planetary Science Letters, 3205(3-4): 123-138.

Bridge JS and Karssenberg D, 2005. Simulation of flow and sedimentary processes, including channel bifurcation and avulsion, on alluvial fans., 8th International Conference of Fluvial Sedimentology, TU Delft, Netherlands, pp. 70.

Bridge JS and Leeder MR, 1979. A simulation model of alluvial stratigraphy. Sedimentology, 26: 617-634.

Bristow CS, 1999. Gradual avulsion, river metamorphosis and reworking by underfitd streams: a modern example from the Brahmaputra river in Bangladesh and a possible ancient example in the Spanish Pyrenees. In: N.D. Smith and J. Rogers (Eds.), Fluvial Sedimentology VI. Special Publication of the International Association of Sedimentologists \#28, pp. 221-230.

Burbank DW and Anderson RS, 2001. Tectonic Geomorphology. Blackwell Science, 274 pp.

Burbank DW, 1996. Causes of the recent Himalayan uplift deduced from deposited pattern in the Ganges Basin. Nature, 357: 680-682.

Burgos JD, 2006. Mise en place et progradation d'un cône alluvial au front d'une chaîne active: exemple des Andes équatoriennes au néogène. Phd Thesis, Université Paul Sabatier, Toulouse 3, Toulouse, $373 \mathrm{pp}$.

Castro M, Mothes P, Hidalgo J, Samaniego P, Hall ML, Galarraga R, Yepes H, Andrade D, Ruiz AG, 2006, Recent numerical modeling of Cotopaxi's lahars, Ecuador, Abstract Cities on Volcanoes 4, Quito, 23-27 January 2006.

Catuneanu O, 2004. Retroarc foreland systems - Evolution through times. Journal of African Earth Sciences, 38: 225-242.

Christophoul F, Baby P, Soula J-C, Rosero M and Burgos JD, 2002. Les ensembles fluviatiles néogènes du bassin subandin d'Equateur et implications dynamiques. Compte Rendus Géosciences, 334: 10291037.

Clapperton CM, Hall M, Mothes P, Hole MJ, Still JW, Helmens KF, Kuhry P, Gemmel AMD, 1997. A younger dryas icecap in the Ecuadorian Andes. Quaternry Research, 47: 13- 28.

Cobb KM, Charles CD, Cheng H and Edwards RL, 2003. El Niño Southern Oscillation and tropical Pacific climate during the last millenium. Nature, 424: 271-276.

DeCelles PG and Giles KA, 1996. Foreland Basin Systems. Basin Research, 8: 105-123.

Demoraes F and d'Ercole R, 2001. Cartografia de riesgos y capacidades en el Ecuador. Diagnostico previo a planes de intervencion de las ONGs, International report. COOPI-IRD-OXFAM, Quito (Ecuador).

Dumont J-F, 1996. Neotectonics of the Subandes-Brazilian craton boundary using geomorphological data: the Marañon and Beni Basin. Tectonophysics, 257: 137-151.

Dumont JF and Hanagarth W, 1993., 1993. River shifting and tectonics in the Beni Basin (Bolivia), Proceedings of the 3rd International Conference of Geomorphology, 23-29 August, Hamilton, ON.

Eguez A, Alvarado A, Yepes H, Machette MN, Costa C, Dart RL, Bradley LA, 2003. Database and Map of Quaternary Faults and Folds of Ecuador and its offshore regions. USGS Open-File Report, 03-289, $71 \mathrm{pp}$.

Ethridge FG, Skelly RL and Bristow CS, 1999. avulsion and crevassing in the sandy, braided Niobrara River: complex response to base-level rise and aggradation. In: N.D. Smith and J. Rogers (Eds.), Fluvial Sedimentology VI. Special Publication of the International Association of Sedimentologists \#28, pp. 180-191.

Fauchet B and Savoyat E, 1973. Esquisse Géologique des Andes de l'Equateur. Revue de Géographie Physique et de Géologie Dynamique, XV(1-2): 115-142.

Friend PF, Jones NE and Vincent SJ. 1999. drainage evolution in active mountain belts: extrapolation backwards from present-day Himalayan river pattern. In: N.D. Smith and J. Rogers (Eds.), Fluvial Sedimentology VI. Special Publication \#28 of the International Association of Sedimentologists. Blackwell, pp. 305-313.

Frost I, 1998. A Holocene sedimentary record from Añangucocha in the Ecuadorian Amazon. Ecology, 69: 66- 73.

Gohain K and Parkash B, 1990. Morphology of the Kosi Megafan. In: AH Rachoki and M Church (Eds.), Alluvial Fans: a field approach. Wiley, pp. 151-178.

Gole CV and Chitale SV, 1966. Inland delta building activity of Kosi River. American Society of Civil Engeneers Journal, Hydraulic Division, HY-2: 111-126.

Gomez N, 1994. Atlas del Ecuador, Geografia y Economia. Imagenes de la Tierra, 3. Editorial Ediguias C. Ltda., Quito, 114 pp.

Guth PL, 2006, Geomorphometry from SRTM: Comparison to NED: Photogrammetric Engineering \& Remote Sensing, 72(3),269-277.

Haberle S, 1997. Late Quaternary vegetation and climate history of the Amazon basin: correlating marine and terrestrial pollen records. Proceedings of the Ocean Drilling Project, Scientific results, 155: 381-396.

Hall M and Beate B, 1991. El volcanismo Plio-Cuaternario en los Andes del Ecuador. Estudios Geograficos, 4: 5- 38.

Hall ML, 1977. El volcanismo en el Ecuador. Publicacion del Instituto Panamericano de Geografia e Historıa, Seccion Nacional del Ecuador., Quito, 120 pp.

Hall, ML, (coord), 1991, The March 5, 1987 Ecuador Earthquake, Mass wasting and socioeconomic effects, The national academic Press, Washington DC, 144pp.

Hall ML, Samaniego P, LePennec J-L and Johnson JB, 2008. Ecuadorian Andes volcanism: A review of Late Pliocene to present activity. Journal of Volcanology and Geothermal Research, 171: 1-6.

Hall ML, Robin C, Beate B, Mothes P and Monzier M, 1999. Tungurahua Volcano, Ecuador: structure, eruptive history and hazards. Journal of Volcanology and Geothermal Research, 91(1): 1-21.

Hansen BCS, Rodbell DT, Seltzer GO, Leon B, young K.R. and Abbott M, 2003. Late-glacial and Holocene vegetational history from two sites in the western Cordillera of southwestern Ecuador. Palaeogeography Palaeoclimatology Palaeoecology, 194: 79-108.

Hastenrath S and Kutzbach J, 1985. Late Pleistocene climate and water budget of the South American Altiplano. Quaternary Research, 24: 249-256.

Hastenrath S, 1981. The glaciation of the Ecuadorian Andes. Balkema, Rotterdam.

Heine K, 2000. Tropical South America during the Last Glacial Maximum: evidence from glacial, peri-glacial and fluvial records. Quaternary International, 72: 7-21. 
Heine K and Heine JT, 1996. Late glacial climatic fluctuations in Makaske B, 2001. Anastomosing rivers: a review of their classification, Ecuador. Glacier retreat during the Younger Dryas time. Arctic and Alpine Research, 28: 496-501.

Heine K, 1994. The Mera site revisited: Ice-age Amazon in the light of new evidence. Quaternary International, 21: 113-119.

Hooghiemstra H and Van Der Hammen T, 1998. Neogene and Quaternary development of the neotropical rain forest: the forest refugia hypothesis, and a literature overview. Earth Science Review, 44(3-4): 147-183.

Horton BK and DeCelles PG, 2001. Modern and ancient fluvial megafans in the foreland basin system of the Central Andes, Southern Bolivia: implications for drainage network evolution of fold-thrust belts. Basin Research, 13: 43-63.

Humphrey NF and Konrad SK, 2000. River incision or diversion in response to bedrock uplift. Geology, 28: 43-46.

Hungerbühler D, Steinman M, Winkler W, Seward D, Egüez A, Peterson DE, Helg U, Hammer C, 2002. Neogene stratigraphy and Andean geodynamics of southern Ecuador. Earth Science Review, 57: 75124.

IGEPN, 2009. http://www.igepn.edu.ec, Instituto Geofisico de la Escuela Politecnica Nacional, Quito, ecuador.

Jones LS and Schumm SA, 1999. Causes of avulsion: an overview. In: ND Smith and J Rogers (Eds.), Fluvial Sedimentology VI. Special Publication of the International Association of Sedimentologists. Blackwell Science, pp. 171-178.

Jones LS and Harper JT, 1998. Channel avulsions and related processes, and large scle sedimentation patterns since 1875, Rio Grande, San Luis Valley, Colorado. Geological Society of America Bulletin, 110(3): 411-421.

Keefer DK, Moseley ME and deFrance S, 2003. A 38000-year record of floods and debris flows in the Ilo region of southern Peru and its relation to El Niño events and great earthquakes. Palaeogeography Palaeoclimatology Palaeoecology, 194: 41- 77. origin and sedimentary products. Earth Science Review, 53: 149-196.

McClay KR, 1992. Glossary of thrust tectonics. In: K.R. McClay (Ed.), Thrust Tectonics. Chapman and Hall, London, pp. 447.

Mégard F, 1984. The Andean Orogenic Period and its Major Structures in Central and Northern Peru. Journal of the Geological Society of London, 141: 893-900.

Montufar R and Pintaud J-C, 2006. Variation in species composition, abundance and microhabitat preferences among western Amazonian Terra Firme palm communities. Botanical Journal of the Linnean Society, 151: 127-140.

Monzier M, Robin C, Samaniego P, Hall ML, Cotten J, Mothes P, Arnaud N, 1999. Sangay volcano, Ecuador: structural development, present activity and petrology. Journal of Volcanology and Geothermal Research, 90(1-2): 49-79.

Morozova GS and Smith ND, 2000. Holocene avulsion styles and sedimentation patterns of the Saskatchewan River, Cumberland Marshes, Canada. Sedimentary Geology, 130: 81-105.

Morozova GS and Smith ND, 1999. Holocene avulsion history of the lower Saskatchewan fluvial system, Cumberland Marshes, Saskatchewan-Manitoba, Canada. In: N.D. Smith and J. Rogers (Eds.), Fluvial Sedimentology VI. Special Publication. International Association of Sedimentologists, pp. 231-249.

Moy CM, Seltzer GO, Rodbell DT, Anderson DM, 2002. Variability of El Niño/Southern Oscillation activity at millennial timescales during the Holocene epoch. Nature, 420, pp. 162- 165.

Nelson BW, 1970. Hydrography, sediment dispersal and recent historical development of the Po River Delta, Italy. In: J.P. Morgan and R.H. Shaver (Eds.), Deltaic Sedimentation, Modern and Ancient. Special Publication. SEPM, pp. 152-184.

Philip H and Meghraoui M, 1983. Structural analysis and interpretation of the surface deformation of the El Asnam earthquake of October 10, 1980. Tectonics, 2(1): 17-49.

Kennerley JB, 1980. Outline of the Geology of Ecuador. Overseas Potts LV, Akyilmaz O, Braun A, Shum CK, 2008. Multi-resolution dune Geological and Mineral Resources, 55: 1-16.

Lang HR, and Welch R, (1994), « Algorithm Theoretical Basis Document for ASTER Digital Elevation Models: », Jet Propulsion Laboratory, May 31, 1994, draft report to the EOS Project.

Latrubesse, E.M., Stevaux, J.C. and Sinha, R., 2007. Tropical Rivers. Geomorphology, 70(3-4): 187-206.

Lavé J and Avouac J-P, 2001. Fluvial incision and tectonic uplift across the Himalaya of Central Nepal. Journal od Geophysical Research, 106(B11): 26,561-26,591.

Lavenu A, Noblet C, Bonhomme MG, Egüez A, Dugas F, Vivier G, 1992. New K-Ar age dates of Neogene and Quaternary volcanic rocks from the Ecuadorian Andes: Implications for the relationship between sedimentation, volcanism, and tectonics. Journal of South American Earth Sciences, 5(3-4): 309-320.

Ledru M-P, Bertaux J, Sifeddine A and Suguio K, 1998. Absence of last glacial maximum records in lowland tropical forests. Quaternary Research, 49: 233- 237.

Leeder MR, Harris T and Kirby MJ, 1998. Sediment supply and climate change: implications for basin stratigraphy. Basin Research, 10: 7 18 .

Legrand D, Baby P, Bondoux F, Dorbath C, Bes de Berc S, Rivadeneira M, 2005. The 1999-2000 seismic experiment of Macas swarm (Ecuador) in relation with rift inversion in subandean foothills. Tectonophysics, 395: 67-80.

Leier AL, DeCelles PG and Pelletier JD, 2005. Mountains, Monsoons and megafan. Geology, 33(4): 289-292.

LePennec J-L, Jaya D, Samaniego P, Ramon P, Moreno Yanez S, Egred J, Van der Plicht J 2008. the AD1300-1700 eruptive periods et Tungurahua vocano, Ecuador, revealed by historical narratives, stratigraphy and radiocarbon dating. Journal of Volcanology and Geothermal Research, 176: 70-81.

Li S and Finlayson B, 1993. Flood management on the lower Yellow River: hydrological and geomorphological perspectives. In: C.R. Fielding (Ed.), Current Research in Fluvial Sedimentology. Sedimentary Geology, 85, pp. 285-296.

Mackey SD and Bridge JS, 1995. Three dimensional model of alluvial stratigraphy: Theory and application. Journal of Sedimentary Research, B65(1): 7-31 morphology using Shuttle Radar Topography Mission (SRTM) and dune mobility from fuzzy inference systems using SRTM and altimetric data, International Journal of Remote Sensing, 29 , 2879. 2901.

Pratt WR, Duque P and Ponce M, 2005. An autochthonous geological model for the eastern Andes of Ecuador. Tectonophysics, 399(1-4): 251-278.

Ramsay J, 1967. Folding and fracturing of rocks. MacGraw-Hill, New York, $568 \mathrm{pp}$

Ramsay JG and Huber MI, 1987. The techniques of modern structural geology, vol2: Folds and Fractures. Academic Press, 307 pp.

Räsänen ME and Linna AM, 1996. Miocene deposits in the Amazonian Foreland Basin. Science, 273: 124, 125

Räsänen ME, Neller R, Salo J and Jungner H, 1992. Recent and ancient fluvial deposition systems in the Amazonian foreland basin, Peru. Geological Magazine, 129: 293-306.

Räsänen ME, Salo JS, Jungnert H and Romero Pittman L, 1990. Evolution of the Western Amazon Lowland Relief: Impact of Andean Foreland Dynamics. Terra Nova, 2: 320-332.

Reimer PJ, Baillie MGL, Bard E, Bayliss A, Beck JW, Bertrand CJH, Blackwell PG, Buck CE, Burr GS, Cutler KB, Damon PE, Edwards RL, Fairbanks RG, Friedrich M, Guilderson TP, Hogg G, Hughen KA, Kromer B, McCormac G, Manning S, Ramsey CB, Reimer RW, Remmele S, Southon JR, Stuiver M, Talamo S, Taylor FW, Van der Plicht J, Weyhenmeyer CE, 2004. INTCAL04 Terrestrial Radiocarbon age calibration, 0-26 Cal kyrs BP. Radiocarbon, 46(3): 1029-1058.

Reynaud C, Jaillard E, Lapierre H, Mamberti M and Mascles G, 1999. Oceanic plateau and island arcs of southwestern Ecuador: their place in the geodynamic evolution of northwestern South America. Tectonophysics, 307: 235-254.

Rodbell DT, Seltzer GO, Anderson DM, Abbott MB, Enfield DB, Newman JH, 1999. A high resolution $\sim 15,000$ record of El-Nino driven alluviation in southwestern Ecuador. Science, 283: 516-519.

Roddaz M, Baby P, Brusset S, Hermoza W and Darrozes J, 2005. Forebulge dynamics and environmental control in Western Amazonia: The case study of the Arch of Iquitos (Peru). tectonophysics, 399(1-4): 87-108. 
Rosseti D and Valeriano MM, 2007. Evolution of the lowest amazon basin modeled from the integration of geological and SRTM topographic data. Catena, 70: 253-265.

Saucier RT, 1994. Geomorphology and Quaternary geologic history of the Lower Mississipi Valley. U.S. Army Corps of Engineers, 1: 1-364.

Schumm SA, Dumont J-F and Holbrook JM, 2000. active tectonics and alluvial rivers. Cambridge University Press, $276 \mathrm{pp}$.

Schumm SA, Erskine WD and Tilleard JW, 1996. Morphology, hydrology, and evolution of the anastomosing Ovens and King Rivers, Victoria, australia. Geological Society of America Bulletin, 108(10): 1212-1224.

Schumm SA, Mosley MP and Weaver WE, 1987. Experimental Fluvial Geomorphology. Wiley Interscience, New York, 411 pp.

Seltzer GO, Rodbell PA, Baker SC, Fritz PM, Tapia HD, Rowe RB, Dunbar RB, 2002. Early warming of Tropical South America at the last glacial transition. Science, 296: 1685-1686.

Singh IB, Parkash B and Gohain K, 1993. Facies anlysis of the Kosi Megafan deposits. Sedimentary Geology, 85(87-113).

Slingerland R and Smith ND, 2004. River avulsion and their deposits. Annual Reviews of Earth and Planetary Science, 32: 257-285.

Smith ND, McCarthy TS, Ellery WN, Merry CL and Ruther H, 1997. Avulsion and anastomosis in the panhandle region of the Okavongo Fan, Botswana. Geomorphology, 20: 49-65.

Spikings RA, Seward D, Winkler W and Ruiz G, 2000. Low temperature thermochronology of the northern Cordillera Real, Ecuador: tectonic insights from zircon and apatite fission track analysis. Tectonics, 19: $648-649$.

Spikings RA and Crowhurst PV, 2004. (U/Th)He thermochronometric constraints on the late Miocene Pliocene development of the northern Cordillera Real and Interandean Depression. Journal of South American Earth Sciences.17:239-251.

Stanistreet IG, Cairncross B and McCarthy TS, 1993. Low sinuosity and meandering bedload rivers of the Okavango Fan: channel confinement by vegetated levees without fine sediment. Sedimentary Geology, 85 (1-4): 135-156.

Stanistreet IG and McCarthy TS, 1993. The Okavango Fan and the classification of subaerial fan systems. Sedimentary Geology, 85: 115-133.

Stinton, A.J., and Sheridan, M.F., 2008, Implications of long-term changes in valley geomorphology on the behavior of small-volume pyroclastic flows, J. Volcanology and Geothermal Research. 176, 134-140,
Stouthamer E and Berendsen HJA, 2001. Avulsion Frequency, Avulsion duration and interavulsion period of the Holocene channel belts in the Rhine-Meuse Delta, The Netherlands. Journal of Sedimentary Research, 71(4): 589-598.

Stouthamer E and Berendsen HJA, 2000. Factors Controlling the Holocene Avulsion History of the Rhine-Meuse Delta (The Netherlands). Journal of Sedimentary Research, 70(5): 1051-1064.

Talling PJ and Sowter MJ, 1998. Erosion, deposition and basin wide variations in stream power and bed shear stress. Basin Research, 10: 87-108.

Törnqvist TE and Bridge JS, 2002. Spatial variation of overbank aggradation rates and its influence on avulsion frequency. Sedimentology, 49: 891-905.

Törnqvist TE, 1994. Middle and late Holocene avulsion history of the River Rhine (Rhine-Meuse Delta, Netherlands). Geology, 22: 711714

Tschopp HJ, 1953. Oil explorations in the Oriente of Ecuador. American Association of Petroleum Geologists Bulletin, 37: 2303-2347.

Vanacker V, von Blanckenburg F, Govers G, Kubik PW, 2007. Transient landscape evolution following uplift in the Southern Ecuadorian Andes, Geochimica and Cosmogenica Acta, 71: A1052.

Vanacker V, von Blanckenburg F, Govers G, Molina A, Poesen J, Deckers J, Kubik P.W, 2007. Restoring natural vegetation reverts mountain erosion to natural levels, Geology, 35: 303-306.

van der Beek P, Champel B and Mugnier J-L, 2002. Control of detachment dip on drainage development in regions of active faultpropagation folding. Geology, 30(5): 471-474.

Welch R and Marko W, (1981), «Cartographic potential of spacecraft line-array camera system: », Stereosat, Photogrammetric Engineering and Remote Sensing, v. 47, n. 8, p.1173-1185.

Weng C, Bush MB, Athens JS, 2002. Holocene climate changeand hydrach succession in lowland Amazonian Ecuador. Review of Palaeobotany and Palynologt 120, 73-90.

Wells NA and Dorr JA, 1987. Shifting of the Kosi River, Northern India. Geology, 15: 204-207.

Winkler W, Villagomez D, Spikings R, Abegglend P, Toblere S and Egüez A, 2005. The Chota basin and its significance for the inception and tectonic setting of the inter-Andean depression in Ecuador. Journal of South American Earth Sciences, 19(1): 5-19.

Zandbergen P, 2008, Applications of Shuttle Radar Topography Mission Elevation Data, Geography Compass, Earth observation, DOI: 10.1111/j.1749-8198.2008.00154.x 


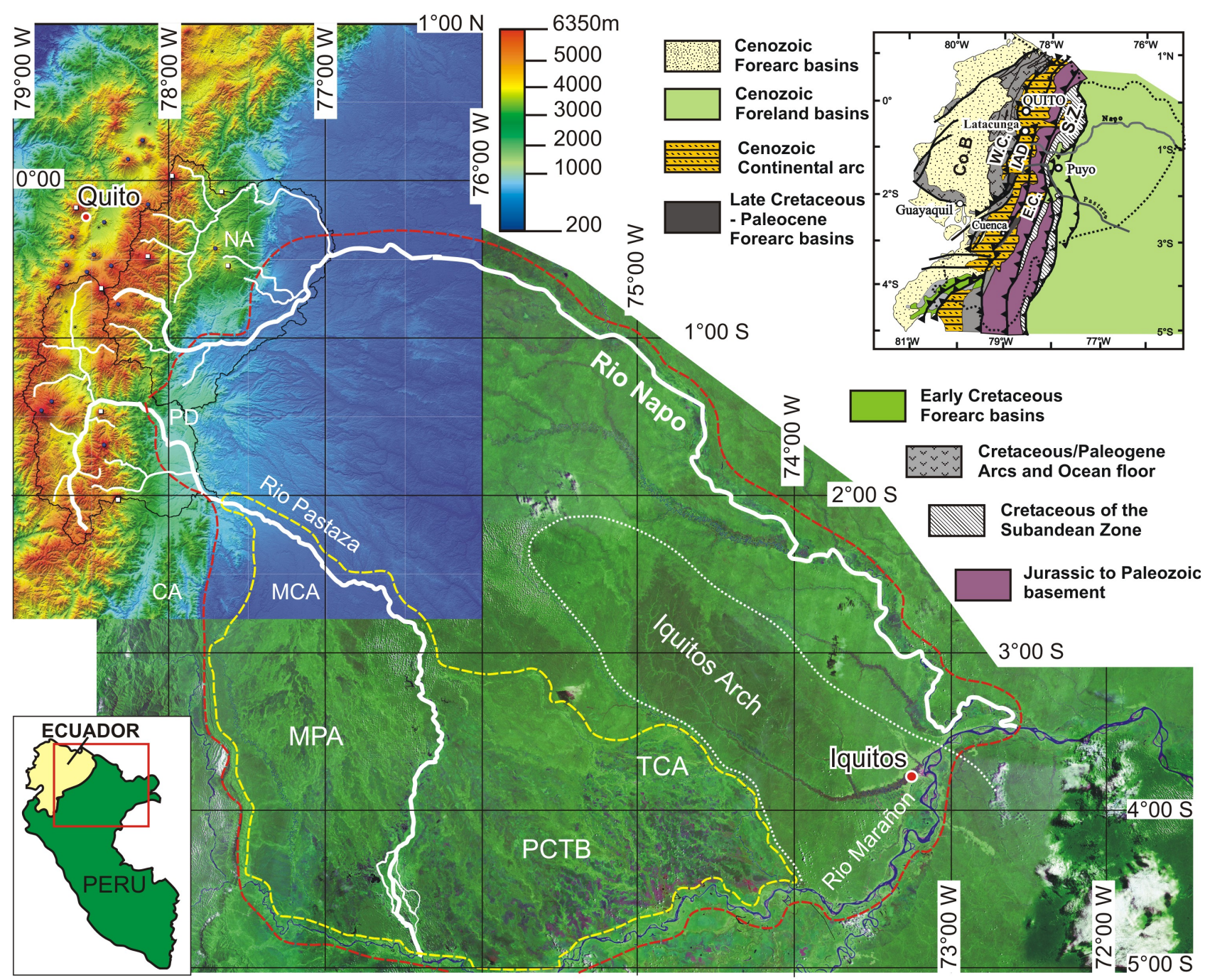

Figure 1: Composite map of the Napo-Pastaza Megafan (DEM SRTM 3" resolution and Landsat 7). Solid black lines: limits of the Napo and Pastaza catchments, solid white lines: modern Rio Napo and Pastaza, red dashed lines: limits of the Plio-Pleistocene Napo Pastaza Megafan, yellow dashed lines: post-LGM Pastaza Megafan. Blue points: volcanoes, white squares: actives volcanoes. NA: Napo Antiform, PD: Pastaza Depression, CA: Cutucu Antiform, MCA: Morona Cangaime Area, MPA: Morona Pastaza Area, TCA, Tigre Corrientes Area, PCTB: Pastaza Corrientes Transition Band. 


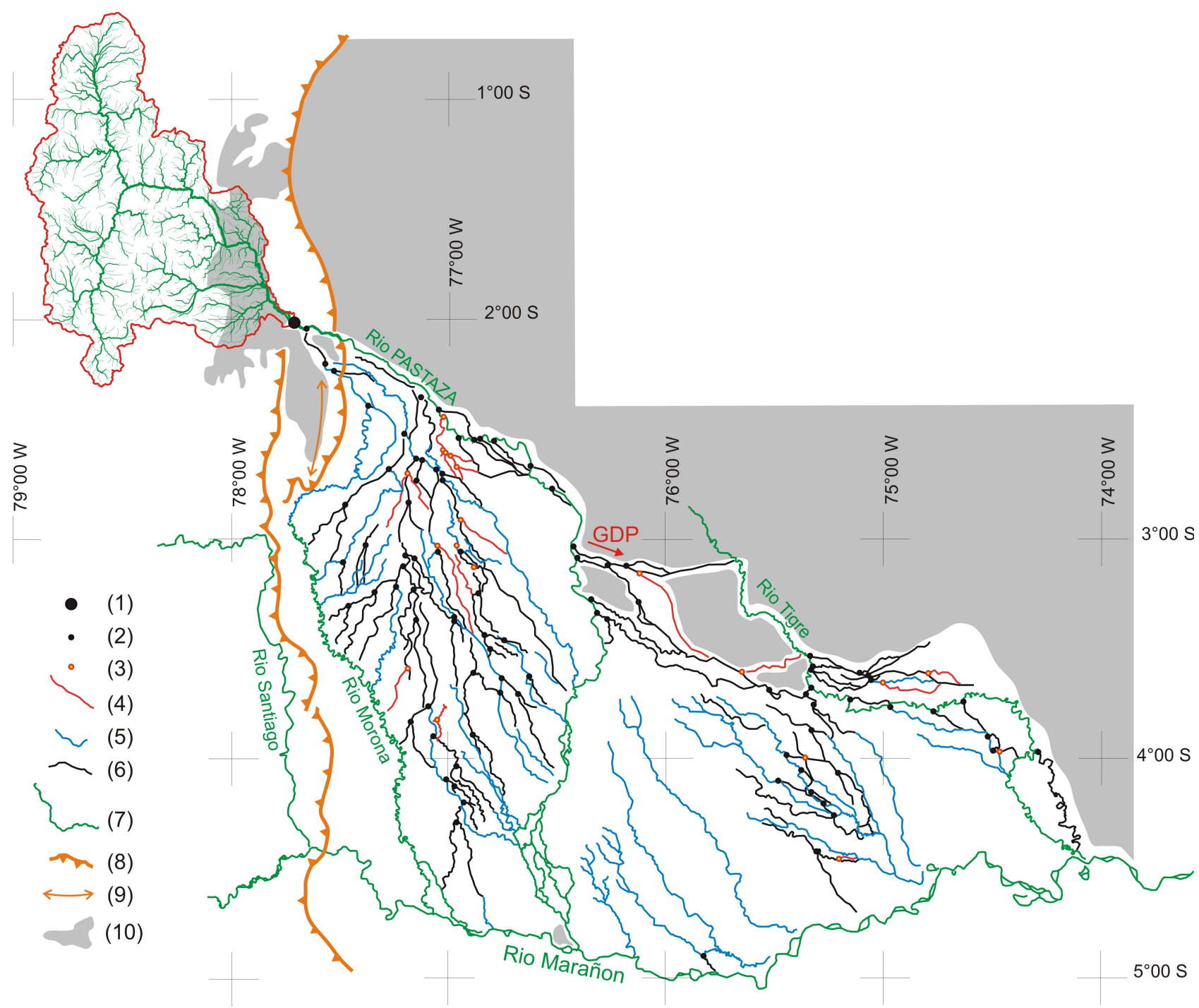

Figure 2: Hydrographic network of the Rio Pastaza basin. To the northwest, with red lines: catchment of the Rio Pastaza Megafan (extracted from the SRTM DEM). With green lines: drainage network. Thickness of lines depends on the Stralher order of the streams. Thinnest lines correspond to Order 3 streams. 1) Modern apex of the Pastaza Megafan, 2) avulsion sites, 3) supposed avulsion sites, 4) abandoned stream, 5) abandoned stream re-annexed by the modern drainage network, 6) supposed abandoned stream, 7) main modern streams, 8) eastern boundary of the subandean tectonic structures, 9) Cangaime anticline axis. 

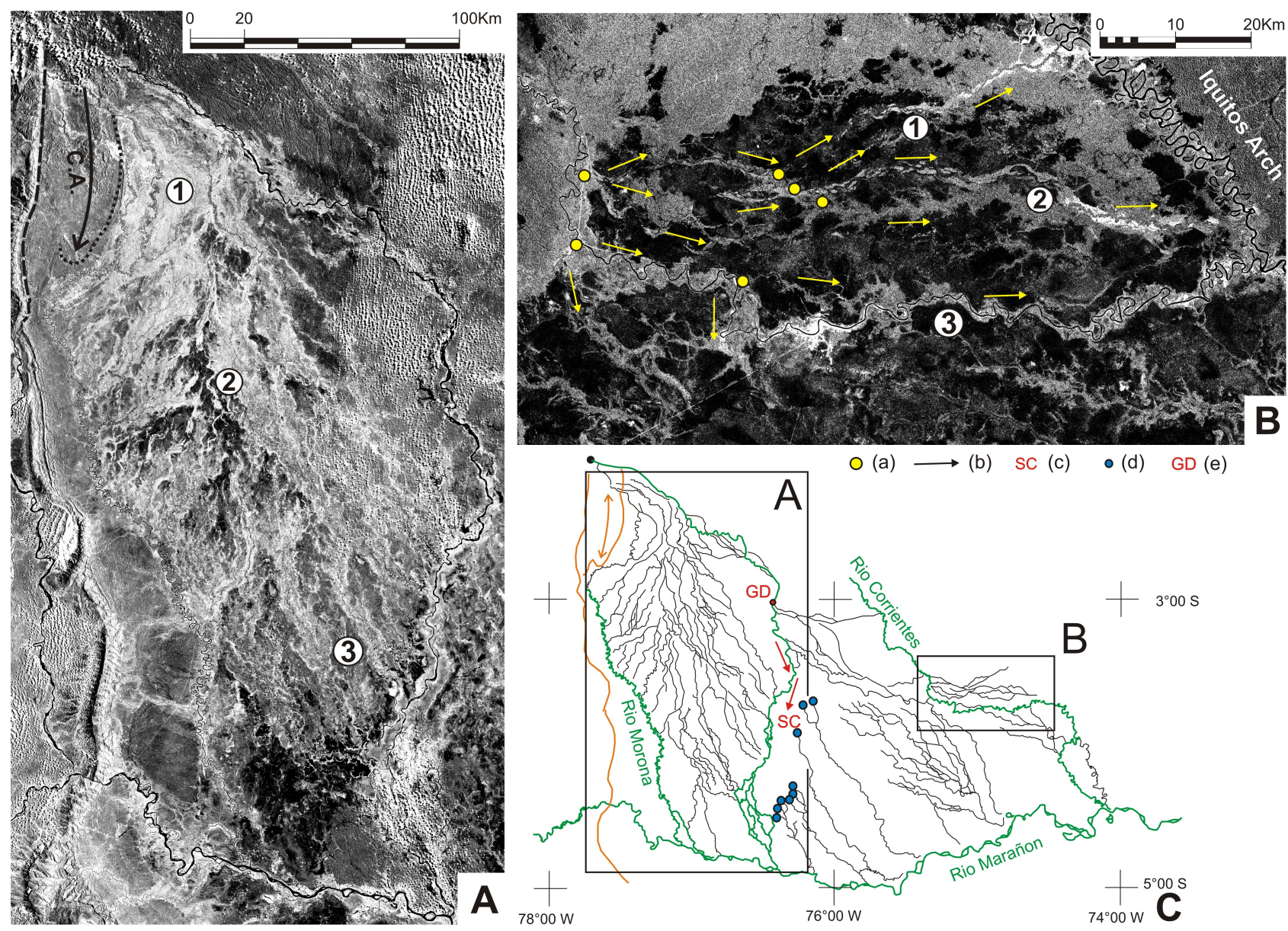

Figure 3: Examples of successives courses and avulsion sites of the Rio Pastaza. A) Morona Pastaza area (MPA), C.A. : Axis of the Cangaime anticline, 1,2 and 3, see text for explanation. B) Northern part of the area of the Rio Tigre and Corrientes (TCA), (a) avulsion sites, (b) plaeocurrents in abandoned reaches, 1,2 and 3, see text for explanation. C) Location map of images A and B within the pastaza megafan. (c) Southern Curve of the Rio Pastaza resulting from the last signficative avulsion of the Rio Pastaza (prior to 1691AD), (d) Streams beheaded as a consequence of the avulsion which gave birth to SC, (e) GDP: avulsion site of the Great Diversion of the Rio Pastaza by mean of which the Rio Pastaza passed from the MPA to the TCA. Image Landsat 7. 


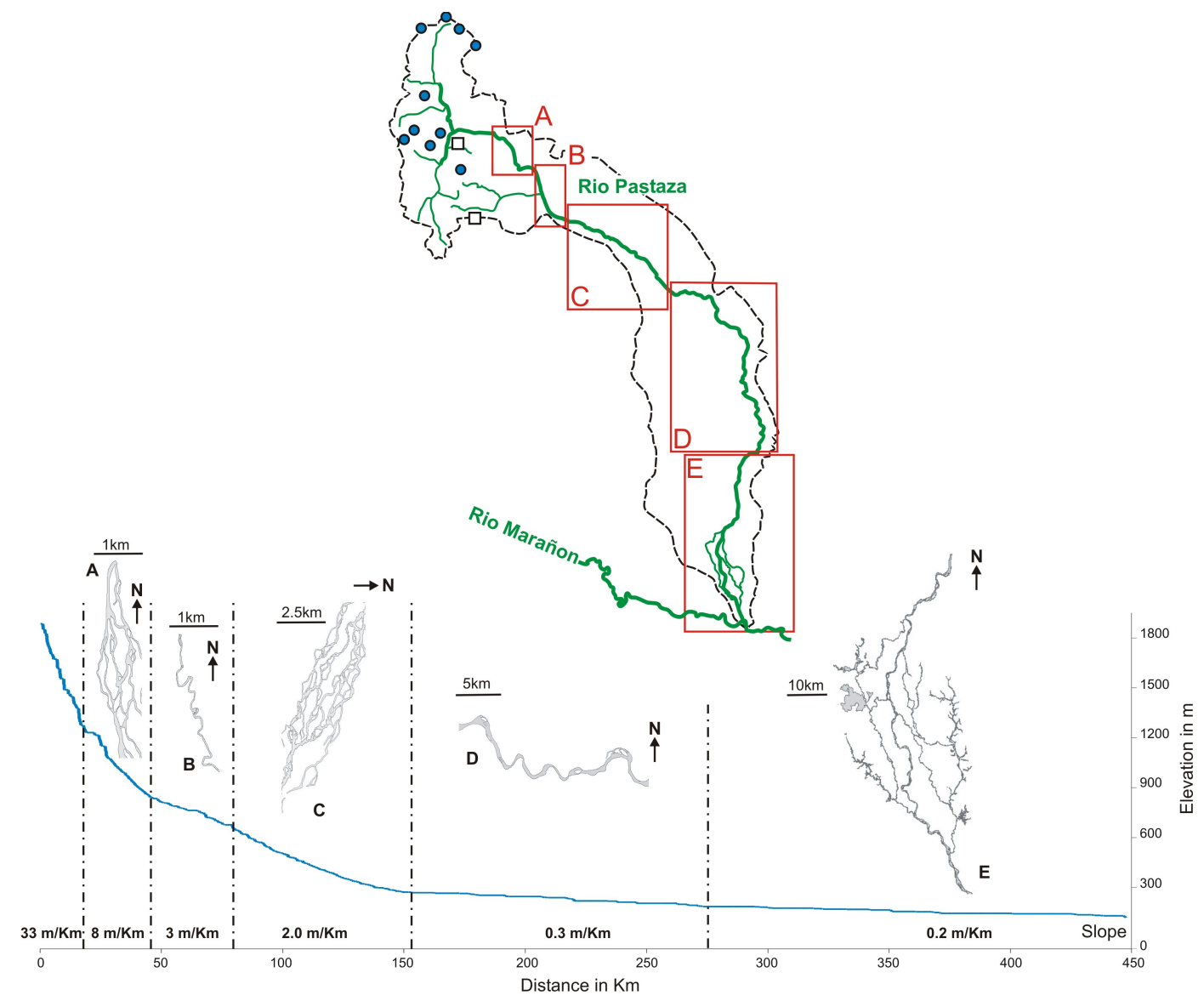

Figure 4: Schematic map of the Rio Pastaza drainage basin, river profile, slope and associated channel pattern of the Rio Pastaza (profile extracted from the SRTM V3 DEM of the area)
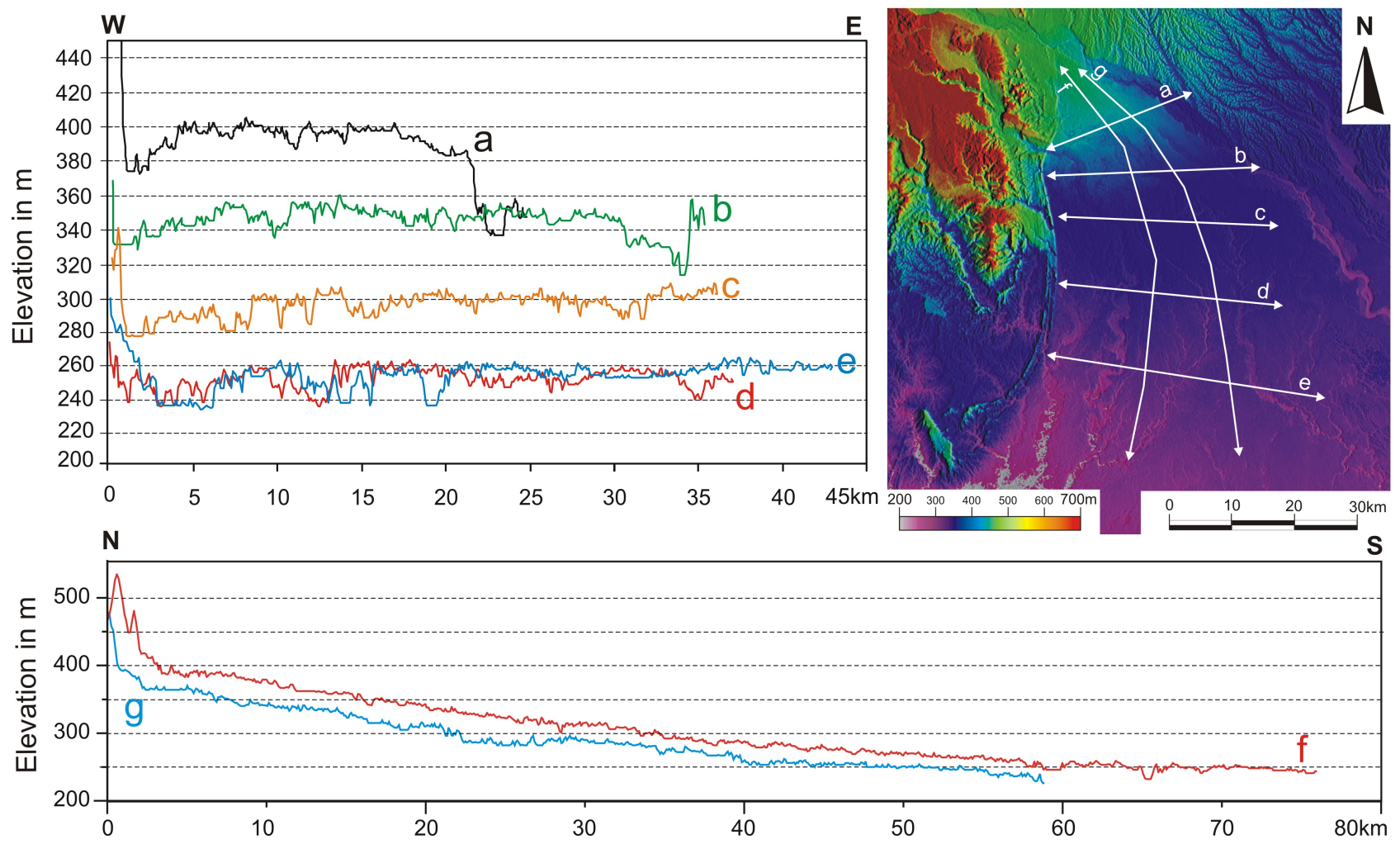

Figure 5: Topographic profiles extracted from the SRTM DEM showing the topography of the upper part of the Pastaza Megafan. 

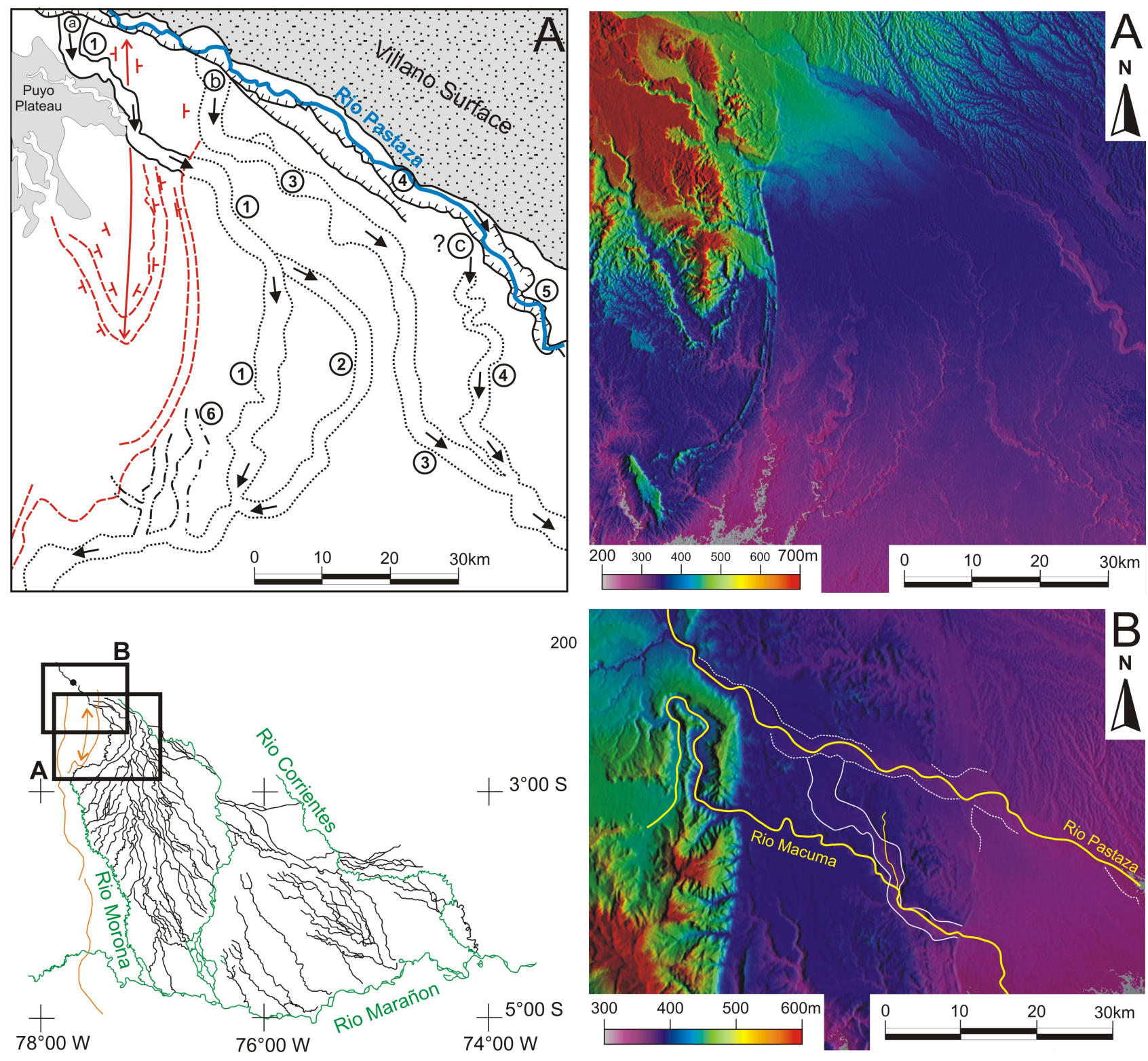

Figure 6: To the left:map of the successive streams of the Rio Pastaza in the MCA. Those streams are bounded by pointed lines. The dasheddouble pointed lines correspond to superimposed streams. Ticked lines indicate terrace scarps, Successive streams of the Rio Pastaza are numbered following chronology. Stream \#5 is the modern Rio Pastaza. To the right: DEM SRTM V3. On the left bank of the Rio Pastaza the characteristic dendritic drainage network developed on top of the Villano surface. Some parts of this surface are also preserved on the right bank. At the bottom: topographic profile across the Pastaza Megafan and the Villano surface, we can quote the strongly dissected aspect of the Villano surface. 

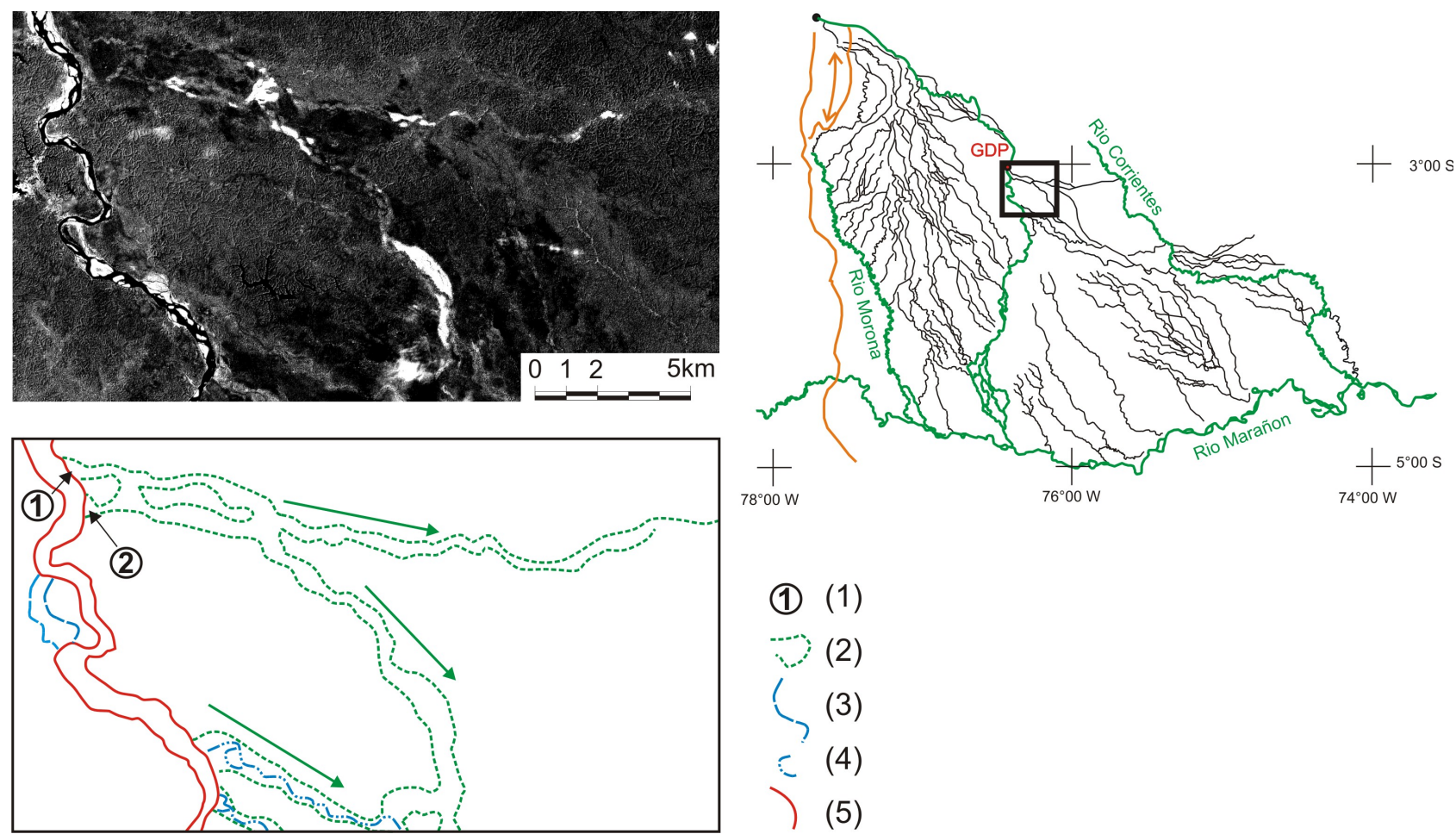

(1) (1)

$(2)$

$(3)$

$<(4)$

$(5)$

Figure 7: Satellite Image and interpretative map of the Great Diversion of the Pastaza are. Observe the sharp contrast between alluvial ridges (even abandoned and the floodplain area. 1) points of avulsion, 2) abandoned alluvial ridges, 3) abandoned loop of the Rio Pastaza, 4) underfitted streams re-occupying abandoned reaches, 5) modern Rio Pastaza Channel.
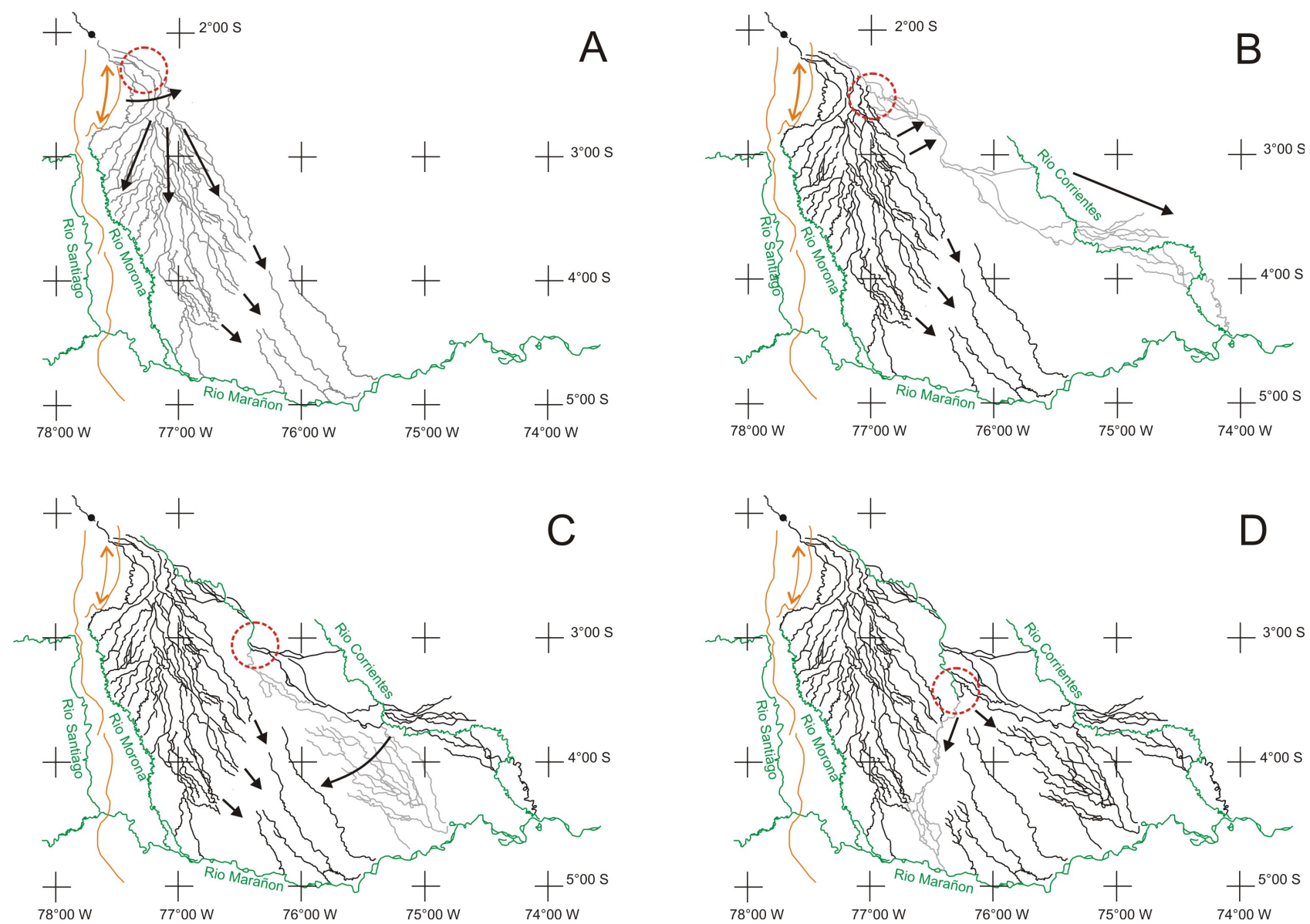

Figure 8: Maps of the migrations of the Rio Pastaza through times. A: Beginning of the avulsions in the Pastaza Megafan. These avulsions occurred after $21160 \pm 260$ yrs Cal BP, B: Great Diversion of the Rio Pastaza to the TCA. C: Avulsions in the TCA, this area was active around $9198 \pm 200$ yrs Cal BP ou $8476+/ 112$ yrs Cal BP, D: Modern morphology of the drainage network resulting form the southward avulsion of the Rio Pastaza and the abandonment of the Rio Tigre/Corrientes area. This configuration is dated after $9198 \pm 200$ yrs Cal BP or $8476 \pm 112$ yrs Cal BP (see text for further explanations). 


\begin{tabular}{|c|c|c|c|c|}
\hline Satellite & \multicolumn{4}{|c|}{ Landsat } \\
\hline years & \multicolumn{2}{|c|}{1990} & \multicolumn{2}{|c|}{2000} \\
\hline mosaics & S-18-00 & S-18-05 & S-18-00 2000 & S18-05- 2000 \\
\hline \# of landsat images & 40 & 38 & 30 & 28 \\
\hline UTM Zone & 18 & 18 & 18 & 18 \\
\hline Upper Latitude & $0^{\circ}$ & $5^{\circ}$ South & $0^{\circ}$ & $5^{\circ}$ South \\
\hline period & $1986 / 03 / 23$ to $1994 / 06 / 30$ & $1986 / 06 / 22$ to $1994 / 07 / 14$ & $1999 / 07 / 11$ to $2001 / 10 / 02$ & $1999 / 07 / 11$ to $2001 / 09 / 20$ \\
\hline Spatial resolution & $28.5 \mathrm{~m}$ & $28.5 \mathrm{~m}$ & $14,25 \mathrm{~m}$ & $14.25 \mathrm{~m}$ \\
\hline Spectral band used & \multicolumn{2}{|c|}{ (TM7, TM4, TM2)+TM8 } & \multicolumn{2}{|c|}{ TM7, TM4, TM2 } \\
\hline Datum & \multicolumn{4}{|c|}{ WGS 84} \\
\hline
\end{tabular}

Table 1:MrSID Image database used for the studied area with their characteristics.

\begin{tabular}{|c|c|c|c|c|c|c|c|c|c|c|c|}
\hline \multicolumn{2}{|c|}{ Scenario } & \multirow{4}{*}{$\begin{array}{l}\text { Time interval } \\
\text { Between } 17920 \pm 70 \mathrm{BP} \text { and } \\
1691 \mathrm{AD} \text { (Bes de Berc et al. } \\
\text { 2005; Fritz in Gomez 1994) }\end{array}$} & \multicolumn{3}{|c|}{ Interval duration (years) } & \multirow{2}{*}{$\begin{array}{l}\text { All } \\
\text { Avulsions } \\
108\end{array}$} & \multicolumn{2}{|c|}{$\begin{array}{l}\text { Recurrence } \\
\text { (years) }\end{array}$} & \multirow{2}{*}{$\begin{array}{l}\text { Most } \\
\text { teliable }\end{array}$} & \multicolumn{2}{|c|}{$\begin{array}{l}\text { Recurrence of } \\
\text { most reliable } \\
\text { (years) }\end{array}$} \\
\hline \multirow[t]{3}{*}{1} & \multirow{3}{*}{$\begin{array}{l}\text { Avulsions since } 17920 \text { years } \\
\mathrm{BP} \text { and } 1691 \mathrm{AD}\end{array}$} & & \multirow{3}{*}{$\begin{array}{l}(21,162 \pm 261)- \\
(1950-1691)\end{array}$} & $21,164^{(1)}$ & \multirow{3}{*}{$20,903 \pm 261$} & & 195 & \multirow{3}{*}{$193 \pm 2$} & & 240 & \\
\hline & & & & 20,903 & & 108 & 193 & & 88 & 237 & $237 \pm 3$ \\
\hline & & & & $20,642^{(2)}$ & & 108 & 191 & & 88 & 234 & \\
\hline \multirow[t]{3}{*}{2} & \multirow{3}{*}{$\begin{array}{l}\text { Avulsions between } 17920 \\
\text { and } 8180 \text { years } \mathrm{BP}\end{array}$} & \multirow{3}{*}{$\begin{array}{l}\text { Between } 17920 \pm 70 \mathrm{BP} \text { and } \\
8180 \pm 120 \mathrm{BP} \text { (Bes de Berc } \\
\text { et al. } 2005 ; \text { Räsanen et al. 1992) }\end{array}$} & \multirow{3}{*}{$\begin{array}{l}(21,162 \pm 261)- \\
(9198 \pm 200)\end{array}$} & $12,425^{(1)}$ & \multirow{3}{*}{$11,964+/ 461$} & 84 & 148 & \multirow{3}{*}{$142 \pm 6$} & 67 & 185 & \\
\hline & & & & 11,964 & & 84 & 142 & & 67 & 179 & $179 \pm 7$ \\
\hline & & & & $11,503^{(2)}$ & & 84 & 137 & & 67 & 172 & \\
\hline \multirow[t]{3}{*}{3} & \multirow{3}{*}{$\begin{array}{l}\text { Avulsions between } 17920 \text { and } \\
7650 \text { years } \mathrm{BP}\end{array}$} & \multirow{3}{*}{$\begin{array}{l}\text { Between } 17920 \pm 70 \mathrm{BP} \text { and } \\
7658 \pm 120 \mathrm{BP} \text { (Bes de Berc } \\
\text { et al. 2005; Räsänen et al. 1992) }\end{array}$} & \multirow{3}{*}{$\begin{array}{l}(21,162 \pm 261)- \\
(8476 \pm 112)\end{array}$} & $13,059^{(1)}$ & \multirow{3}{*}{$12,686 \pm 373$} & 84 & 155 & \multirow{3}{*}{$151 \pm 4$} & 67 & 195 & \\
\hline & & & & 12,686 & & 84 & 151 & & 67 & 189 & $189 \pm 6$ \\
\hline & & & & $12,313^{(2)}$ & & 84 & 147 & & 67 & 184 & \\
\hline \multirow[t]{3}{*}{4} & \multirow{3}{*}{$\begin{array}{l}\text { Avulsions between } 8180 \text { years } \\
\mathrm{BP} \text { and } 1691 \mathrm{AD}\end{array}$} & \multirow{3}{*}{$\begin{array}{l}\text { Between } 8180 \pm 120 \mathrm{BP} \text { and } \\
1691 \mathrm{AD} \text { (Räsänen et al. 1992; } \\
\text { Fritz in Gomez 1994) }\end{array}$} & \multirow{3}{*}{$\begin{array}{l}(9,198 \pm 200)- \\
(1950-1691)\end{array}$} & $9,139^{(1)}$ & \multirow{3}{*}{$8,939 \pm 200$} & 24 & 381 & \multirow{3}{*}{$372 \pm 9$} & 21 & 435 & \\
\hline & & & & 8,939 & & 24 & 372 & & 21 & 426 & $426 \pm 10$ \\
\hline & & & & $8,739^{(2)}$ & & 24 & 364 & & 21 & 416 & \\
\hline \multirow[t]{3}{*}{5} & \multirow{3}{*}{$\begin{array}{l}\text { Avulsions between } 7650 \text { years } \\
\mathrm{BP} \text { and } 1691 \mathrm{AD}\end{array}$} & \multirow{3}{*}{$\begin{array}{l}\text { Between } 7658 \pm 120 \mathrm{BP} \text { and } \\
1691 \mathrm{AD} \text { (Räsänen et al. 1992; } \\
\text { Fritz in Gomez 1994) }\end{array}$} & \multirow{3}{*}{$\begin{array}{l}(8,476 \pm 112)- \\
(1950-1691)\end{array}$} & $8,329^{(1)}$ & \multirow{3}{*}{$8,217 \pm 112$} & 24 & 347 & & 21 & 397 & \\
\hline & & & & 8,217 & & 24 & 342 & $342 \pm 5$ & 21 & 391 & $391 \pm 6$ \\
\hline & & & & $8,105^{(2)}$ & & 24 & 338 & & 21 & 386 & \\
\hline
\end{tabular}

Table 2: Ages, conversions $14 \mathrm{C}$ ages/Calendar ages and computing of avulsions recurrence of the Rio Pastaza. Conversions $14 \mathrm{C}$ ages/Calendar ages were done following the INTCAL04 (Reimer et al., 2004). Columns "All avulsions" and "Global recurrence" take in account all the avulsions sites identified in the area (see Figure 4) while columns "Most reliable" and "Recurrence of most reliable" do not take in account the "supposed sites of avulsion" of Figure 2. (1) upper limit value, (2) lower limit value.

\begin{tabular}{|c|c|c|c|c|c|c|c|c|c|}
\hline \multirow[b]{3}{*}{ Avulsions } & \multicolumn{3}{|c|}{ Rio Pastaza Megafan } & \multirow{2}{*}{\multicolumn{2}{|c|}{$\begin{array}{l}\begin{array}{l}\text { Rhine-Meuse } \\
\text { delta }\end{array} \\
\text { Stouthamer } \\
\text { and Berendsen } \\
(2000,2001)\end{array}$}} & \multirow{3}{*}{$\begin{array}{l}\text { Saskatchewan } \\
\text { Morozova } \\
\text { and Smith } \\
(1999,2000) \\
9\end{array}$} & \multirow{3}{*}{$\begin{array}{l}\text { Kosi Megafan } \\
\text { Gole and } \\
\text { Chitale (1966) } \\
12\end{array}$} & \multirow{3}{*}{$\begin{array}{l}\text { Taquari } \\
\text { Megafan } \\
\text { Assine (2005) } \\
3\end{array}$} & \multirow{3}{*}{$\begin{array}{l}\text { Brahmaputra } \\
\text { river } \\
\text { Bristow (1999) } \\
7\end{array}$} \\
\hline & This study & & & & & & & & \\
\hline & $108^{(1)}$ & $84^{(2)}$ & $24^{(3)}$ & $27^{(4)}$ & $87^{(4)}$ & & & & \\
\hline Interval (years) & $\sim 21,000$ & $\sim 12,300$ & $\sim 8,500$ & 3,875 & 6,370 & 5,400 & $246(1731-1977)$ & $30(1973-2003)$ & $202(1776-1978)$ \\
\hline Recurrence (years) & $\sim 195$ & $\sim 145$ & $\sim 354$ & 143 & 73 & 600 & 20.5 & 10 & 29 \\
\hline Average frequency (years) & $0.51 / 100$ & $0.68 / 100$ & $0.28 / 100$ & $0.7 / 100$ & $1.4 / 100^{(4)}$ & $0.17 / 100$ & $4.88 / 100$ & $10 / 100$ & $3.47 / 100$ \\
\hline
\end{tabular}

Table 3: Comparison of morphological parameters between the Pastaza Megafan and its catchment and other megafans. (1) Water discharge computed following the formula $Q=k a . A^{\alpha}$ with $Q:$ discharge in $\mathrm{m}^{-3}, A:$ surface of the drainage basin in $\mathrm{km}^{2}, \mathrm{ka}=0.049$ et $\alpha=0.96$ (Talling and Sowter 1998). (2) Streampower by length unit $\Omega=\gamma$. .Q.s, with $\gamma$, specific weight of water $\left(9810 \mathrm{~N} . \mathrm{m}^{-3}\right)$, Q: discharge in m.s. ${ }^{-3}$, local slope in $\mathrm{m} . \mathrm{m}^{-1}$. (3) et (4) : (Bes de Berc et al. 2005). (5), after (Horton and DeCelles 2001). (6), after (Lavé and Avouac 2001). (7) after (Singh et al. 1993). (8) incision values of (Lavé and Avouac 2001) corresponding to the Main Boundary Thrust area for the Arun and Sun Kosi rivers, close to the Apex of the Kosi megafan.

\begin{tabular}{|c|c|c|c|c|c|c|}
\hline & $\begin{array}{l}\text { Catchment } \\
\text { surface }\left(\mathrm{km}^{2}\right)\end{array}$ & $\begin{array}{l}\text { Fan surface } \\
\left(\mathrm{km}^{2}\right)\end{array}$ & $\begin{array}{l}\text { Fan/catchment } \\
\text { ratio }\end{array}$ & $\begin{array}{l}\text { Discharge } \\
\left(\mathrm{m} \mathrm{s}^{-3}\right)^{(1)}\end{array}$ & $\begin{array}{l}\text { Streampower } \\
\left(\mathrm{W} \mathrm{m}^{-1}\right)^{(2)}\end{array}$ & $\begin{array}{l}\text { Incision values } \\
\left(\mathrm{mm} \mathrm{year}^{-1}\right)\end{array}$ \\
\hline Rio Pastaza & 13,700 & 51,400 & 3.75 & 458 & $2.64 \times 10^{4}$ & $4.3^{(4)}$ \\
\hline MPA & 13,700 & 13,750 & 1 & 458 & $2.64 \times 10^{4}$ & $4.3^{(4)}$ \\
\hline Rio Grande, Bolivia & $\sim 70,000^{(5)}$ & $\sim 12,600^{(5)}$ & 0.18 & 2,195 & $5.10 \times 10^{4}$ & $\mathrm{n} / \mathrm{a}$ \\
\hline Rio Pilcamayo & $81,300^{(5)}$ & $\sim 22,600^{(5)}$ & 0.28 & 2,534 & $2.76 \times 10^{4}$ & $\mathrm{n} / \mathrm{a}$ \\
\hline Rio Parapeti & $\sim 8,000^{(5)}$ & $\sim 5,800^{(5)}$ & 0.72 & 273 & $2.73 \times 10^{2}$ & $\mathrm{n} / \mathrm{a}$ \\
\hline Kosi River & $51,370^{(6)}$ & $\sim 10,000^{(7)}$ & 0.19 & 1,631 & $5.12 \times 10^{4}$ & $1.5-2.5^{(8)}$ \\
\hline
\end{tabular}

Table 4: Comparison of avulsion recurrence data between the Rio Pastaza megafan and other fluvial systems known for their frequent avulsions: the Rhine-Meuse delta (Stouthamer and Berendsen 2000); (Stouthamer and Berendsen 2001); the Saskatchewan river (Morozova and Smith 1999; Morozova and Smith 2000), the Kosi river megafan (Gole and Chitale 1966) and the Rio Taquari megafan (Assine 2005). (1) scenario 1 in table 2, (2) scenario 2 and 3 in Table 2, (3) scenario 4 and 5 in Table 2, (4) tectonically triggered avulsions that occurred between 5500 and 1625 BP (Stouthamer and Berendsen 2000), (5) avulsions which occurred between 7395 and 1000 BP (Stouthamer and Berendsen 2000), (6) between 1731 and 1977 (Gole and Chitale 1966; Wells and Dorr 1987). 